\title{
Expected versus unexpected monetary policy impulses and interest rate pass-through in eurozone retail banking
}

Citation for published version (APA):

Sander, H., \& Kleimeier, S. (2004). Expected versus unexpected monetary policy impulses and interest rate pass-through in eurozone retail banking. METEOR, Maastricht University School of Business and Economics. METEOR Research Memorandum No. 001 https://doi.org/10.26481/umamet.2004001

Document status and date:

Published: 01/01/2004

DOI:

10.26481/umamet.2004001

Document Version:

Publisher's PDF, also known as Version of record

\section{Please check the document version of this publication:}

- A submitted manuscript is the version of the article upon submission and before peer-review. There can be important differences between the submitted version and the official published version of record.

People interested in the research are advised to contact the author for the final version of the publication, or visit the DOI to the publisher's website.

- The final author version and the galley proof are versions of the publication after peer review.

- The final published version features the final layout of the paper including the volume, issue and page numbers.

Link to publication

\footnotetext{
General rights rights.

- You may freely distribute the URL identifying the publication in the public portal. please follow below link for the End User Agreement:

www.umlib.nl/taverne-license

Take down policy

If you believe that this document breaches copyright please contact us at:

repository@maastrichtuniversity.nl

providing details and we will investigate your claim.
}

Copyright and moral rights for the publications made accessible in the public portal are retained by the authors and/or other copyright owners and it is a condition of accessing publications that users recognise and abide by the legal requirements associated with these

- Users may download and print one copy of any publication from the public portal for the purpose of private study or research.

- You may not further distribute the material or use it for any profit-making activity or commercial gain

If the publication is distributed under the terms of Article $25 \mathrm{fa}$ of the Dutch Copyright Act, indicated by the "Taverne" license above, 


\section{Limburg}

Institute

\section{of \\ Financial \\ Economics}

\section{UFE Working Paper 03 - 032}

\section{“Expected versus Unexpected Monetary Policy Impulses and Interest Rate Pass-Through in Eurozone Retail Banking"}

By

Stefanie Kleimeier and Harald Sander
Limburg Institute of Financial Economics

life@berfin.unimaas.n|

Department of Finance Maastricht University

P.O. Box 616 6200 MD Maastricht The Netherlands

$T+31433883838$

$F+31433884875$

This paper is available at:

http://www.fdewb.unimaas.nl/finance/ workingpapers 
Version: November 11, 2003

\title{
EXPECTED VERSUS UNEXPECTED MONETARY POLICY IMPULSES AND INTEREST RATE PASS-THROUGH IN EUROZONE RETAIL BANKING
}

\author{
by \\ Stefanie Kleimeier ${ }^{\text {a,* }}$ \\ and \\ Harald Sander ${ }^{b}$
}

\begin{abstract}
:
This paper follows up on recent studies of the Eurozone interest rate pass-through. Using a generalized empirical approach that allows for a variety of different specifications of the pass-through, including asymmetric adjustment, the role of interest rate expectations, proxied by EURIBOR futures, in determining retail banking product pricing is explored. It is shown that the pass-through is faster when monetary policy changes are correctly anticipated. However, this result is limited to the loan market and is here more pronounced for positive interest rate shocks, while particularly deposit rates are found to be rigid, suggesting an important role of competitive banking markets for the pass-through process. Overall, our results show that a well-communicated monetary policy is important for a speedier and a more homogenous pass-through and thus for a more effective monetary policy in the Eurozone.
\end{abstract}

JEL Classification Numbers: E43, E52, E58, F36

Keywords: Interest Rates, Interest Rate Expectations, Monetary Policy, European Monetary Union, European Banking, EURIBOR Futures, Competition in Banking, Asymmetric Adjustment, Cointegration Analysis, Threshold Cointegration.

a) Maastricht University, Limburg Institute of Financial Economics \& METEOR, P.O. Box 616, NL-6200 MD Maastricht.

b) University of Applied Sciences Cologne, Claudiusstr.1, D-50678 Köln and METEOR Extramural Fellow, Maastricht University.

*corresponding author: email: s.kleimeier@berfin.unimaas.nl, phone:+31-43-3883733 fax: +31-433884875 


\section{Introduction}

Investigating the pass-through of monetary policy impulses onto retail banking interest rates has become an important part of the research on the financial part of the monetary transmission process in the Eurozone as its results have direct implications for assessing the efficiency of the monetary policy, the heterogeneity (or a possible trend towards homogeneity) of the Eurozone financial system, and the competitive situation in different segments of the banking markets. While this research area is fairly well developed by now, the complete absence of interest rate expectations and monetary policy anticipation from the literature is striking. In the presence of forward looking financial markets, and in particular the existence of interest rate futures, such as EURIBOR futures, which may act as a measure of expected future interest rates, pricing behaviour in retail banking is likely to be forward looking too. The present study will explore this issue by disentangling the impact of expected and unexpected monetary policy impulses and discuss the impact of a well-communicated monetary policy on the Eurozone interest rate pass-through.

Following the pioneering pass-through study by Cottarelli and Kourelis (1994) who are applying a VAR model in an international context, this approach had soon been adopted within the European context (Cottarelli, Ferri, and Generale 1995, BIS 1994, Borio and Fritz 1995). Following Sander and Kleimeier (2000) pass-through studies are now regularly based on an error-correction specification (e.g. Mojon 2000, Heinemann and Schüler 2001, Toolsema, Sturm and de Haan 2002). Most recently, asymmetric adjustment of retail bank rates to monetary impulses has also been considered. This until now relatively small literature (see e.g. Sander and Kleimeier 2000, 2002, de Bondt 2002, 
and de Bondt, Mojon, and Valla 2002) builds on Tong (1983), Scholnick (1996, 1999), Balke and Fomby (1997), Enders and Granger (1998), Baum and Karasulu (1998), and Enders and Siklos (2000). Eurozone pass-through studies commonly find the following pattern: First, bank interest rates are sticky. Monetary policy rate changes typically lead to a less than one-to-one change of retail rates, i.e. the short and medium-run multipliers are taking values often far below unity. Second, there are considerable differences in the pass-through across different bank lending and deposit rates. Third, studies that allow for asymmetric adjustment depending on the type of monetary policy shock typically find ample evidence for asymmetries, but these asymmetries show no consistent pattern. Fourth, while there is no consensus yet regarding a possible full pass-through in the long run, most authors agree that the pass-through is most complete with respect to short-term lending to enterprises. Fifth, most studies find significant differences in the pass-through mechanism across the Eurozone countries. Finally, there is increasing, though still weak evidence that the pass-through mechanism has become faster and more homogeneous in the recent years, potentially pointing to the role of the Euro and the single Eurozone monetary policy. Nevertheless, the remaining differences in existing literature are still high. In Sander and Kleimeier (2003) we have tried to unify this research by arguing as follows: First, these differences are caused by predominantly by differences in (1) the choice of exogenous market interest rate, (2) the length and timing of the investigated periods, (3) the treatment of possible structural breaks, and (4) the chosen methodology for the pass-through study. Second, these differences could be reconciled by focussing on a unifying approach that uses an appropriate measure of the monetary policy stance such as short-run money market rates, incorporates endogenous determination of structural 
breaks, and introduces an automatic model selection out of a vast variety of possible pass-through models allowing for asymmetric and threshold adjustment. Doing so, we find that breakpoints are typically occurring some years before monetary union has commenced, thus pointing to the important role of forward looking behaviour in financial markets. Comparing then pre- and post-break pass-through behaviour, we confirm the results of previous studies that report stickiness of short-run adjustment of retail interest rates in the Eurozone. Nevertheless an increased speed of the pass-through in the postbreak period is confirmed. Moreover, we find a large number of banking markets with a less than perfect long-run pass-through. This suggests that market imperfections such as credit rationing may have remained an important feature in European retail banking. The view that Eurozone banking markets are still fragmented is supported, with the eventual exemption of short-term lending to enterprises. Finally, analysing the determinants of the pass-through we find that competition, banking market integration, a stable monetary policy regime, or a more homogeneous growth performance are all important variables for homogenizing the pass-through and thus monetary transmission in the Eurozone while legal and cultural differences may, however, preclude full convergence.

In this paper we extend this unifying approach to the pass-through of monetary policy impulses onto retail banking by introducing a distinction between expected and unexpected monetary policy changes. As financial markets are forward looking, it can be argued that changes in policy rate may already be priced into retail banking interest rates well before the actual changes in the monetary policy occur. For example, in the context of the US mortgage market Sellon (2002) has argued that in the recent years "both mortgage rate and market interest rate appear to anticipate monetary policy actions", i.e. 
they rose somewhat before episodes of monetary tightening and fell well before decreases in federal funds target rates. Consequently, if retail interest rates anticipate changes in monetary policy rates, the measured short- and medium-term multipliers may not convey a correct picture of the pass-through process. A related issue is the impact of correct anticipation of the ECB's policy actions on the speed of the pass-through process, thus pointing to the role of a frictionless communication between the central bank and the market. Moreover, the irregular pattern of asymmetries across countries and banking products found in previous studies may reflect a differential behaviour with respect to expected and unexpected shocks. By differentiating between both we want to shed some more light on the stickiness of bank product prices. Finally, it could be argued that with a single monetary policy the anticipation of monetary policy action will also become more uniform across the Eurozone and thus contribute to a more homogenous pass-through.

The plan of the paper is as follows. In section 2 we introduce our measurement of expected and unexpected monetary policy shocks by making use of EURIBOR futures to measure expected interest rates - which is novel in the pass-through literature. In section 3 we briefly describe our methodology. Section 4 reports the results of our analysis and section 5 concludes with a view on improving the pass-through process in the Eurozone.

\section{Data}

In order to differentiate between expected and unexpected shocks we follow Kuttner (2001) who - in the US context - has made use of the federal funds future market as an indicator for anticipated monetary policy rate. Unfortunately, in the Eurozone no futures on ECB policy rates are available. However, Bernoth and von Hagen (2003) 
analyse 3-months EURIBOR futures and conclude that these rates are unbiased and efficient predictors of future spot interest rates. These authors also assert that "market participants understand the policy decisions of the Central Bank and on average are able to predict them precisely. Nevertheless some Governing Council decisions still cause leading market participants to revise their interest rate forecasts. Thus the ECB's information policy can be improved." Consequently, we differentiate between expected and unexpected monetary policy impulses such that

$$
\mathrm{MP}=\mathrm{MPU}+\mathrm{MPE}
$$

where MP is the realized monetary policy rate, MPE is the expected and MPU the unexpected monetary policy rate. As a proxy for the monetary policy rate (MP) the European Interbank Offered Rate (EURIBOR) for 1-month euro time deposits is chosen. This choice is motivated by the fact that futures exist on this underlying asset which can be used to estimate MPE and MPU. ${ }^{1}$ In contrast to Bernoth and von Hagen (2003) who use a 3-months future that only matures four times a year, the 1-month future has the advantage that at any given point in time, futures maturing in the next six calendar months are being traded. Thus, we are able to create a monthly MPE series, which matches the monthly frequency of the bank interest rates. Furthermore, the short-term nature of the underlying asset, the 1-month euro deposit, better reflects the central bank's monetary policy rate than any longer-term interest rate.

Based on the daily data for each future contract provided by Eurex, MP is measured by the final settlement price of the future ${ }^{2}$. Given the standardized maturity of

\footnotetext{
${ }^{1}$ In particular, we opted for the FEU1 futures contract traded on Eurex in Frankfurt as a proxy for monetary policy expectations.

${ }^{2}$ The final settlement price of a future is established by Eurex at 11:00 a.m. CET on the last trading day (LTD) and is based on the EURIBOR rate for one-month euro time deposits as established by the
} 
the future two trading days before the third Wednesday of each month, the future's final settlement price reflects the monetary policy rate approximately in the middle of the calendar month. The expected monetary policy rate MPE is defined based on the daily settlement price of the future. ${ }^{3}$ As these daily settlement prices are available up to six months before the last trading day (LTD) of each future, a choice has to be made which of these daily settlement prices serves as a proxy of MPE. The LTD of the future falls typically between the $13^{\text {th }}$ and the $19^{\text {th }}$ of the month. As such, a daily settlement price 12 to 16 trading days before maturity covers for all futures the beginning of the calendar month. Thus, MPE is defined as the equally weighted average of the daily settlement prices from 12 to 16 trading days before the LTD of the future and as such approximates the expected monetary policy rate at the beginning of the calendar month ${ }^{4}$.

The unexpected component of the monetary policy MPU can now simply be calculated as MP minus MPE. Figure 1 shows the time series graphs of all three series. As the comparison between MPE and MP shows, futures rates follow very closely the realised monetary policy rates. As such MPU, the unexpected component of the monetary policy impulses, centres around zero. Unit root tests confirm this random nature of MPU as it is found to be $\mathrm{I}(0)$. On the other hand, both MP and MPE are I(1). As such, regressing MP on MPE (see Panel A of Table A2 in the Appendix) can be interpreted in two ways. First, it represents the standard test of the unbiasedness of futures where

FBE/ACI. In particular, the final settlement price is calculated as 100 minus the EURIBOR, which has been rounded to the nearest price interval $(0.005 ; 0.01$; or a multiple thereof), The LTD is two exchange trading days prior to the third Wednesday of the respective settlement month with trading ending at 11 a.m.

${ }^{3}$ Eurex's trading hours are 8.45 a.m. until 7.00 p.m. CET. Eurex defines the daily settlement price as "the volume-weighted average price of the last five trades of the day, provided they are not older than 15 minutes - or, if more than five trades have occurred during the final minute of trading, then the volumeweighted average price of all trades that occurred during that period".

${ }^{4}$ We also tried alternative specifications of MPE such as averages over different trading days or one-day settlement prices, but the basic tenor of the results remains unchanged. 
futures are found to be unbiased if $\theta_{0}=0$ and $\theta=1^{5}$. In line with Bernoth and von Hagen's (2003) results for 3-months EURIBOR futures, we can also confirm unbiasedness for the 1-month EURIBOR futures market. Second, the regression can be interpreted as a cointegration relationship between the two series. The Durbin-Watson (DW) and DickeyFuller (DF) tests clearly support the existence of such a cointegration relationship. Expected monetary policy rates MPE can therefore be visualized as temporarily deviating from monetary policy rates (and thus leading to non-zero realizations of MPU) but reverting back to monetary policy rate MP in the long run.

[Insert Figure 1 about here]

Given the data limitation for EURIBOR futures and acknowledging that our previous analyses indicated structural breaks mostly before the introduction of the Euro we concentrate in the following on the EMU period starting January 1, 1999. Our study is based on monthly national retail interest rates for Austria, Belgium, Finland, France, Germany, Ireland, Italy, Netherlands, Portugal and Spain ${ }^{6}$ that have been obtained from the ECB. The ECB provides six different loan rates: Three consumer lending rates for overdrafts on cash accounts (N1), mortgage loans to households (N2), and consumer loans to households (N3); two corporate lending rates for short-term loans to enterprises (N4), and medium and long-term loans to enterprises (N5); and a final category for other lending rates (N6). In addition, the ECB collects three different deposit rates for current

\footnotetext{
${ }^{5}$ For a discussion and application of this approach see Cole, Impson and Reichenstein (1991), Krehbiel and Adkins (1994), Cole and Reichenstein (1994), Krueger and Kuttner (1996), and Bernoth and van Hagen (2003).

${ }^{6}$ Greece has been excluded because it did not join EMU until January 2001.
} 
account deposits (N7), time deposits (N8), and savings accounts (N9); and a final category for other deposit rates (N10). We collect these data on a monthly basis from January 1999 to May 2003. ${ }^{7}$

\section{Methodology}

In this study, we follow a methodology developed by Sander and Kleimeier (2002). As a starting point we employ the "standard pass-through model" which is a simple VAR model used by Cottarelli and Kourelis (1994),

$$
\mathrm{BR}_{\mathrm{t}}=\beta_{0}+\sum_{\mathrm{i}=1}^{\mathrm{k}^{*}} \beta_{\mathrm{BR}, \mathrm{i}} \mathrm{BR}_{\mathrm{t}-\mathrm{i}}+\beta_{1} \mathrm{MP}_{\mathrm{t}}+\sum_{\mathrm{i}=1}^{\mathrm{n}^{*}} \beta_{\mathrm{M}, \mathrm{i}} \mathrm{MP}_{\mathrm{t}-\mathrm{i}}+\varepsilon_{\mathrm{t}}
$$

where $\mathrm{BR}_{\mathrm{t}}$ and $\mathrm{MP}_{\mathrm{t}}$ are bank and policy rates. The optimal lag length is indicated by $\mathrm{k}^{*}$ and $n^{*}$, respectively. The impact multiplier is estimated by the coefficient $\beta_{1}$, where a value of less than 1 indicates sluggish adjustment, also known as lending rate stickiness. The long-term multiplier can be calculated from (2) as

$$
\theta=\frac{\beta_{1}+\sum_{\mathrm{i}=1}^{\mathrm{n}^{*}} \beta_{\mathrm{MP}, \mathrm{i}}}{1-\sum_{\mathrm{i}=1}^{\mathrm{k}^{*}} \beta_{\mathrm{BR}, \mathrm{i}}}
$$

so that in the long run equation (2) takes the form

$$
\mathrm{BR}_{\mathrm{t}}=\theta_{0}+\theta \mathrm{MP}_{\mathrm{t}}
$$

A full pass-through in the long run is reflected by $\theta=1$.

The novelty that is introduced in this study is the differentiation between expected and unexpected monetary policy rate components, i.e. MP is replaced by MPE and MPU,

\footnotetext{
${ }^{7}$ For details on data, see the ECB's National Retail Interest Rates - Methodological Notes. Only bank lending and deposit rates available in monthly frequency are included. Thus, quarterly series available for France are not included in the sample.
} 
as defined in equation (1). While the long-run relationship remains unchanged, the VAR model now takes the following specification ${ }^{8}$.

$$
\mathrm{BR}_{\mathrm{t}}=\beta_{0}+\sum_{\mathrm{i}=1}^{\mathrm{k}^{*}} \beta_{\mathrm{BR}, \mathrm{i}} \mathrm{BR}_{\mathrm{t}-\mathrm{i}}+\beta_{\mathrm{E}} \mathrm{MPE}_{\mathrm{t}}+\beta_{\mathrm{U}} \mathrm{MPU}_{\mathrm{t}}+\varepsilon_{\mathrm{t}}
$$

Note that as futures are unbiased forecasts of monetary policy rates, any unexpected monetary impulses can be interpreted as temporary and should as such be accounted for in the next months' futures rate. This impression is supported by the finding discussed above that MP and MPE are cointegrated and that MPU is $\mathrm{I}(0)$. As such, introducing lags of MPE or MPU would not be appropriate and would only lead to multicollinearity problems.

The model of equation (5) is considered as our standard model in levels (STD_LL) but is only valid if interest rates time series are not integrated. If, what is commonly the case, interest rates are integrated of degree 1, the model has to be estimated in first differences. As such, two model specifications have to be considered:

$$
\begin{gathered}
\Delta \mathrm{BR}_{\mathrm{t}}=\beta_{0}+\sum_{\mathrm{i}=1}^{\mathrm{k}^{*}} \beta_{\mathrm{BR}, \mathrm{i}} \Delta \mathrm{BR}_{\mathrm{t}-\mathrm{i}}+\beta_{\mathrm{E}} \Delta \mathrm{MPE}_{\mathrm{t}}+\beta_{\mathrm{U}} \Delta \mathrm{MPU}_{\mathrm{t}}+\varepsilon_{\mathrm{t}} \\
\Delta \mathrm{BR}_{\mathrm{t}}=\beta_{0}+\sum_{\mathrm{i}=1}^{\mathrm{k}^{*}} \beta_{\mathrm{BR}, \mathrm{i}} \Delta \mathrm{BR}_{\mathrm{t}-\mathrm{i}}+\beta_{\mathrm{E}} \Delta \mathrm{MPE}_{\mathrm{t}}+\beta_{\mathrm{U}} \Delta \mathrm{MPU}_{\mathrm{t}}+\beta_{\mathrm{ECT}} \mathrm{ECT}_{\mathrm{t}-1}+\varepsilon_{t}
\end{gathered}
$$

Model (6) is our standard model (STD) and is appropriate when interest rates are I(1) but $\mathrm{BR}$ and MP are not cointegrated. When interest rates are found to be I(1) and cointegrated, simply estimating model (6) to avoid spurious regression problems causes a loss of important information about the long-run relationship. This information can be obtained from the cointegration regression

\footnotetext{
${ }^{8}$ In this as in all other models, the optimal number of lags is selected via the AIC criterion and a maximum of 4 lags is allowed.
} 


$$
\mathrm{BR}_{\mathrm{t}}=\theta_{0}+\theta \mathrm{MP}_{\mathrm{t}}+\mathrm{u}_{\mathrm{t}}
$$

and should be fed into the pass-through model, such as given by equation (7). In this model $\mathrm{ECT}_{\mathrm{t}-1}$, the estimated error term $\mathrm{u}_{\mathrm{t}-1}$ of the cointegration regression, is included with its coefficient $\beta_{\mathrm{ECT}}$ reflecting the speed of adjustment to the long-run cointegrating equilibrium. In all three models (5) to (7), $\beta_{\mathrm{E}}$ and $\beta_{\mathrm{U}}$ represent the impact multipliers with respect to expected and unexpected monetary policy shocks. The long-run multiplier can either be found as $\theta$ from the cointegration regression (8) or - when interest rates are not cointegrated - can be estimated based on the coefficients of equation (5) or (6) as

$$
\theta=\frac{\beta_{\mathrm{E}}+\beta_{\mathrm{U}}}{1-\sum_{\mathrm{i}=1}^{\mathrm{k}^{*}} \beta_{\mathrm{BR}, \mathrm{i}}}
$$

We allow for six different types of cointegration relationships and test which of these type fits the data best. First, there can be a symmetric cointegration relationship between $\mathrm{BR}$ and MP as defined by Engle and Granger (1987) such that $\mathrm{ECT}_{\mathrm{t}-1}=\mathrm{u}_{\mathrm{t}-1}$ from equation (8). Cointegration is based on the Durbin-Watson (DW), Dickey-Fuller (DF) and augmented Dickey-Fuller (ADF) testing procedures. This specification assumes that bank rates immediately adjust to any, however small deviation from the long-run equilibrium and that the adjustment is the same for negative as for positive deviations. As the other five models are using a modified version of the ADF test, the DF and ADF test for this symmetric model should be noted in comparison. The DF test is based on

$$
\Delta \mathrm{ut}_{\mathrm{t}}=-\delta_{0} \mathrm{ut}_{-1}+\varepsilon \mathrm{t}
$$

and the $\mathrm{ADF}$ test is obtained from the regression

$$
\Delta \mathrm{u}_{\mathrm{t}}=-\delta_{0} \mathrm{u}_{\mathrm{t}-1}+\sum_{\mathrm{i}=1}^{\mathrm{c}^{*}} \delta_{\mathrm{i}} \Delta \mathrm{u}_{\mathrm{t}-\mathrm{i}}+\varepsilon_{\mathrm{t}}
$$


where the optimal lag length $c^{*}$ is found based on the minimum Akaike information criterion (AIC) criteria with a maximum of four lags.

Second, there could be asymmetric adjustment of BR to MP in the sense that the adjustment of BR depends on its relation to the equilibrium level. For example, if MP increases without an immediate adjustment in the lending rate, we obtain a negative realization of the error term $u_{t}$. When the autoregressive decay is faster for MP increases than for MP decreases, then the lending rate adjusts faster upward than downward. Such an asymmetric adjustment pattern can be modelled with a threshold autoregressive model $\left(\mathrm{TAR}^{0}\right)$ as developed by Tong (1983), where the ECT is split into its positive and negative elements. In particular, a Heaviside indicator $I_{t}$ is set for different states of $u_{t-1}$.

$$
I_{t}=\left\{\begin{array}{lll}
1 & \text { if } & u_{t-1} \geq 0 \\
0 & \text { if } & u_{t-1}<0
\end{array}\right.
$$

For this model, we can test for cointegration by estimating

$$
\Delta u_{t}=I_{t} \rho_{1} u_{t-1}+\left(1-I_{t}\right) \rho_{2} u_{t-1}+\sum_{i=1}^{m^{*}} \rho_{2+i} \Delta u_{t-i}+\varepsilon_{t}
$$

with the optimal lag length $\mathrm{m} *$ determined via the minimum AIC criteria for models with up to four lags. As a modified ADF test, the estimated F-statistic for $\mathrm{H}_{0}: \rho_{1}=\rho_{2}=0$ serves as a cointegration test. Furthermore, an F-test for $\mathrm{H}_{0}$ : $\rho_{1}=\rho_{2}$ indicates the presence of asymmetry. For both tests, critical values are provided by Enders and Siklos (2000).

Third, we extend the model to allow for a non-zero threshold. For example, the BR will adjust fast only when it deviates from its long-term equilibrium relationship with MP by more than some optimal threshold $\mathrm{a}_{0} *$ of, say, 20 basis points. For lower deviations, adjustment would eventually take place at a significantly slower pace. Such 
behaviour can be modelled with a TAR* model, for which the Heaviside indicator in conjunction with equation $(13)^{9}$ is defined as

$$
I_{t}=\left\{\begin{array}{lll}
1 & \text { if } & u_{t-1} \geq a_{0}^{*} \\
0 & \text { if } & u_{t-1}<a_{0}^{*}
\end{array}\right.
$$

To determine the optimal threshold $\mathrm{a}_{0} *$ we follow Chan (1993) and search over the mid$80 \%$ of the distribution of $u_{t}$ and select the model for which the residual sum of squares is minimized. Cointegration and asymmetry testing proceeds with the above described Ftests.

Forth, we consider adjustment processes consistent with either menu-cost or interest-smoothing behaviour. To illustrate the interest rate stickiness driven by menucost, consider a situation where deviations from equilibrium are small such that they fall into a narrow band bordered by $\mathrm{a}_{0} *$ and $-\mathrm{a}_{0} *$. Inside this band, no adjustment will take place and thus no cointegration can be detected. Only outside this band, for example below $-\mathrm{a}_{0}{ }^{*}$, the benefits from increasing lending rates outweigh the associated menu-cost and adjustment will take place. Interest rate smoothing is reflected by the opposite behaviour when adjustment takes place and thus cointegration is found inside the band but not outside. Here banks protect customers against excessive - but potentially temporary - deviations from equilibrium. Such behaviour can be modelled with a BandTAR* model $^{10}$, based on a Heaviside indicator defined as

$$
I_{1}=\left\{\begin{array}{llllll}
I_{1}=1 & \text { if } & u_{t-1} \geq a_{0}^{*} & \text { and } & 0 & \text { otherwise } \\
I_{2}=1 & \text { if } & \left|u_{t-1}\right|<a_{0}^{*} & \text { and } & 0 & \text { otherwise } \\
I_{3}=1 & \text { if } & u_{t-1}<-a_{0}^{*} & \text { and } & 0 & \text { otherwise }
\end{array}\right.
$$

Equation (13) has then to be modified to

$$
\Delta u_{t}=\sum_{j=1}^{3} \rho_{j} I_{j} u_{t-1}+\sum_{i=1}^{m^{*}} \rho_{3+i} \Delta u_{t-i}+\varepsilon_{t}
$$

\footnotetext{
${ }^{9}$ For both, the TAR* and the following B-TAR* model, the optimal lag length $\mathrm{m}^{*}$ of the $\mathrm{TAR}^{0}$ specification is used.

${ }^{10}$ For applications of this B-TAR* model to interest rate cointegration where infrequent and discrete adjustments in the rates occur see for example Balke and Fomby (1997) or Baum and Karasulu (1998).
} 
Procedures for optimal lag length $\mathrm{m}^{*}$ and optimal threshold $\mathrm{a}_{0} *$ are corresponding to those of the TAR* and the F-tests for cointegration and asymmetry are applied to all three coefficients $\rho_{j}$.

As the fifth and sixth adjustment processes, we consider M-TAR ${ }^{0}$ and M-TAR* processes based on Enders and Granger (1998). Here, a different type of interest rate smoothing is modelled where the speed of the ECT is of importance ${ }^{11}$. The Heaviside indicator in conjunction with equation (13) is now defined as

$$
I_{t}=\left\{\begin{array}{lll}
1 & \text { if } & \Delta u_{t-1} \geq a_{0} \\
0 & \text { if } & \Delta u_{t-1}<a_{0}
\end{array}\right.
$$

A threshold can be set as $\mathrm{a}_{0}=0$ leading to the $\mathrm{M}-\mathrm{TAR}^{0}$ specification or be optimised at $\mathrm{a}_{0}$ $=\mathrm{a}_{0} *>0$ leading to the M-TAR* specification. $^{12}$

To distinguish which of these six models best fits the data, we consider the following sequence of tests. We first test all interest rates for unit roots. If rates are found to be $\mathrm{I}(1)$, we secondly estimate the cointegration relationship and obtain the residuals $\hat{\mathrm{u}}_{\mathrm{t}}$. Third, we estimate all five TAR-type models and select the model with the smallest AIC value. For this optimal TAR model, we test for cointegration and asymmetry. If asymmetric cointegration is confirmed, we define the error-correction process (as measured by the ECT) based on this optimal TAR-type model. In case that asymmetric cointegration is not confirmed, we test for symmetric cointegration. Only after symmetric cointegration is rejected we estimate the standard pass-through model in levels or first differences depending on the results of the unit root tests. Finally after the optimum pass-

\footnotetext{
${ }^{11}$ M-TAR models have been successfully applied to the term structure of interest rates by for example Enders and Granger (1998) and Enders and Siklos (2000).

${ }^{12}$ When optimising the threshold in the M-TAR* model, the optimal lag length $\mathrm{m}^{*}$ from the M-TAR ${ }^{0}$ is used.
} 
through model is selected, multipliers are obtained for a variety of positive and negative interest rate shocks. ${ }^{13}$

\section{$\underline{\text { 4. Results }}$}

In order to select the optimal pass-through model, we start with the unit root testing and report the results in Table A1 of the appendix. As expected all bank rates have the I(1) or sometimes I(2) property and as such we can proceed with the cointegration testing of BR and MP. Table A2 reports results of both, the estimation of the long-run relationship of equation (7) and the symmetric cointegration tests. Overall, 40 out of 72 series $(55.6 \%)$ are symmetrically cointegrated. However, if the true nature of the cointegration relationship is asymmetric, these tests might be misspecified. We therefore conduct asymmetric cointegration tests that reveal which pass-through model would be best specified for the country and interest rate under consideration. Based on the results reported in Table A3 of the appendix, of all 72 long-run relationships between the bank rate and monetary policy rate, 14 pairs of series $(19 \%)$ are symmetrically cointegrated, 41 pairs of series $(57 \%)$ are asymmetrically cointegrated, and 17 pairs of series $(24 \%)$ show

13 As already noted in Sander and Kleimeier (2003), two peculiarities of the asymmetric models should be taken into account when estimating multipliers: First, multipliers cannot simply be obtained by comparing two sets of forecasts - with and without changes in the explanatory variable - at any point in time because the speed of adjustment in asymmetric pass-through models depends on the model's estimated error. Therefore, such multipliers apply only to the particular context but cannot be generalized. In order to obtain state-independent multipliers, we calculate them based on an equilibrium situation. In particular, we force the change in the expected and unexpected monetary policy rates to zero at the end of each estimation period and allow the retail bank rate to converge to an equilibrium, before the impact of a shock in the expected or unexpected monetary policy rates is simulated. The multipliers are then calculated based on the resulting retail bank rate's adjustment. Note that some asymmetric pass-through models may not converge to an equilibrium. In such cases, we would only obtain state dependent multipliers. To avoid this, we decided to select the next-best converging asymmetric model based on the AIC criterion or - in extreme problem cases - the symmetric or standard pass-through model. Details regarding the finally selected optimal or next-best models are given in Tables B3 and B4 of Appendix B. These tables also show that non-convergence is a rather rare problem. Second, multipliers are also varying with the specific type of the shock as the reaction of bank rates depends on the size and direction of the monetary policy shock. 
no cointegration. Note also that in all cases of asymmetric adjustment, a non-zero threshold is chosen as a best fit for the data. These findings are in line with Sander and Kleimeier (2003) and highlight yet again the importance of asymmetric and threshold modelling in pass-through analyses.

Focussing now on the characteristics of the pass-through process, our long-run results are largely in line with the pass-through literature as long-run multipliers are often below 1 with the notable exemption of short-term lending to enterprises. Turning to impact multipliers and the short-run dynamics - again in line with the literature - we find considerable stickiness in bank rates. To illustrate that, in a first step, two sets of multipliers are calculated: One for $\mathrm{a}+1 \%$ shock in MPE, the other for a $+1 \%$ shock in MPU. The results are summarized in Figure 2. Details on a country and rate level are listed in Table A4 of the appendix. Figure 2 illustrates how bank rates on average react to both, expected as well as unexpected monetary policy shocks and clearly reveals the incomplete and sluggish pass-through. Furthermore, for all rates except time deposits, the reaction to expected monetary policy impulses appears to be larger than to unexpected impulses as MPE multipliers are larger than the MPU multipliers. ${ }^{14}$

[Insert Figure 2 about here]

For practical purposes, it would also be interesting to find out how bank rates react to a simultaneous shock in both MPE and MPU. Simply shocking both rates by

\footnotetext{
${ }^{14}$ It should however be pointed out here, that due to the structure of the pass-through model, i.e. the fact that it does not include any lags of MPE or MPU, a larger impact multiplier will be followed by larger interim multipliers as the only adjustment in the interim occurs due to the ECT and the lags of the bankrate. These coefficients are however the same for MPE as for MPU shocks.
} 
$+1 \%$, however, is not feasible. Looking at the series as displayed in Figure 1, it is clear that the size and volatility of MPE and MPU are different with an average MPE of 3.61\% and MPU of $0.015 \%$ and standard deviations of $0.785 \%$ and $0.1076 \%$, respectively. Thus, whereas the analysis in Figure 2 and Table A4 are useful on a purely comparative basis, a $+1 \%$ shock for MPU would be quite unrealistic. A more realistic comparison could be based on the relative volatilities of the two series. A $+1 \%$ shock in the overall MP rate could consist of an $0.8795 \%$ shock in MPE (based on the relative standard deviation of MPE as $0.7850 /(0.7850+0.1076)$ ) and an $0.1205 \%$ shock in MPU (based on the relative standard deviation of MPU as $0.1076 /(0.7850+0.1076))$. The results of such an analysis are presented in Table 1. Note that the effect of the joint shock is in most cases simply the sum of the two individual shocks. Sometimes, however, when the data is characterized by asymmetries, the joint shock can lead to a larger or a smaller shock than the sum of the individual shocks. Examples of such cases are mortgage rates in Belgium and Portugal, short-term corporate loan rates in Belgium, France, and Ireland, or long-term corporate rates in Finland and Ireland. Given the fact that more than half of our series are characterized by asymmetric adjustment, one should not underestimate this effect. Finally, a comparison can be made between the joint shock to MPE and MPU as reported in Table 1 and a $+1 \%$ shock to the realized monetary policy rate MP as reported in Table 2. Here clearly recognizable differences in the size of the pass-through occur for most countries, rates, and time-horizons. Even if no clear direction can be identified, these results strongly support our case: Market expectations matter in the pass-through and disregarding them leads to an incorrect perception of the pass-through process. 
[Insert Table 1 about here]

[Insert Table 2 about here]

On a statistically more sophisticated base, our multipliers allow for testing of several interesting hypotheses. To do so, we constructed a panel consisting out of all positive and negative shock multipliers for both, expected and unexpected shocks, thus leading to a total of 260 observations. First, we test whether bank rates react significantly faster to expected than to unexpected shocks as suggested by Figure 2. We therefore regress a dummy for expected monetary policy shocks on the impact and interim multipliers. In a second step of this exercise we also control for country and bank rate specifics by using the appropriate dummies. While in a first attempt we did not find statistically significant evidence for a special anticipated monetary policy effect, this result changes when using separate dummies for deposits and loans, thus pointing to differential effects in both markets ${ }^{15}$. The first set of regressions in Table 3 shows that the pass-through of expected market rate changes is significantly faster, but only for loans and not for deposits. To explore this issue further we have also made the same estimates for separated panels for positive and negative multipliers, which are reported in Table 4. Anticipated rate increases, measured by a $+1 \%$ shock, will statistically significant increase the pass-through in the loan markets up to 3 months. More specifically, banks will increase lending rates faster when they expect increases in market interest rates, but deposit rate will not be raised any faster. When looking into negative shocks some differences to the positive shock effects and - in this sense - some degree of asymmetry

\footnotetext{
${ }^{15}$ We are grateful to Robert DeYoung for suggesting this regression framework.
} 
can be found. I.e. the downward adjustment of lending rates for anticipated rate decreases is only significant for the impact and 1-month multipliers.

[Insert Table 3 about here]

[Insert Table 4 about here]

In order to explore asymmetries further, we use the large panel to test directly for downward and upward symmetries in deposit and loan markets, regardless whether the shocks are anticipated or unanticipated. Without country and rate dummies, we clearly identify significantly slower upward adjustments of deposit rates, thus pointing to upward rigidities of deposit rate. Using all rate and country dummies the statistical significance of this result diminishes somewhat in the very short run, but nevertheless we can even here find slower deposit rate adjustment for the 3- to 12-months multipliers. Our results can thus be understood as evidence for price rigidity in the banking industry in the sense of Hannan and Berger (1991) who have demonstrated that US deposit rate show clear signs of upward rigidity.

Finally, we use our pass-through results to test for the impact of interest-rate expectations on the homogeneity of the Eurozone pass-through. For doing so, we define convergence as the standardized variation of the respective impact and interim multipliers as $\left|\theta_{\mathrm{j}, \mathrm{s}, \mathrm{t}}-\theta_{\text {Mean, } \mathrm{s}, \mathrm{t}}\right| \theta_{\text {Mean, s,t }} .{ }^{16}$ To test whether expected shocks lead to less divergence we regress the convergence variable on expected shock dummies, which are again separated for deposits and loans. The results, reported in Table 5, show that expected monetary

\footnotetext{
${ }^{16}$ Note that the subscripts indicate country $\mathrm{j}$ (Austria to Spain), shock s (MPE versus MPU shock), and time horizon $t$ (impact to 12 -months multipliers). Thus, each multiplier is compared to the cross-country average multiplier for its respective type of shock s and time horizon $t$.
} 
shocks lead to a higher degree of homogeneity in the Eurozone pass-through in loan, but not in deposit markets. However, the homogenizing effect is less pronounced for negative shocks, again pointing to the important role different national financial market structures. The result therefore suggests that although a well-communicated monetary policy will be very helpful in creating a more uniform Eurozone pass-through, the importance of a competitive retail banking market must also be highlighted.

[Insert Table 5 about here]

In sum, the point can be made that a well-anticipated, well-communicated monetary policy goes some way to speed-up and homogenize the pass-through process and thus improve the effectiveness of monetary policy in the Eurozone. However, this would only constitute a complement to and not a substitute for competitive markets.

\section{$\underline{\text { 5. Conclusions }}$}

Our paper extends the traditional pass-through literature by introducing a distinction between expected and unexpected monetary policy impulses. Among the most important conclusion are, first, that this novel approach can be considered to be an important addition to the literature as a significant positive impact of interest rate anticipation on the pass-through can statistically be proven. Secondly, given the faster response of retail banking rates to anticipated monetary policy impulses, our results point to the important role of a good central bank policy communication policy for monetary policy effectiveness. Thirdly, we find severe asymmetries in retail banking price 
behaviour, in particular a more sluggish behaviour of deposit rate, thus highlighting the importance of price rigidity in the banking industry. It should be noted that the earlier findings in the literature that asymmetries are present but do show irregular pattern are not confirmed here. In particular with respect to anticipated interest rate changes the asymmetries show quite clear pattern that point to role of imperfect competitive markets. Fourth, and consequently, while a transparent central bank policy is helpful for speeding up the pass-through, it is no substitute for competitive markets. Finally and under similar reservations regarding competitive banking markets, our results point to the potential role of a good central bank communication policies in harmonizing the Eurozone passthrough. 
$\underline{\text { Appendix }}$

[Insert Tables A1 to A4 here] 


\section{$\underline{\text { References }}$}

Balke, N.S., Fomby, T.B., 1997. Threshold cointegration. International Economic Review 38 (3), 627-645.

Bank for International Settlements (BIS), 1994. National differences in interest rate transmission. CB Document 393, Basle.

Baum, C.F., Karasulu, M., 1998. Modelling Federal Reserve discount policy. Computational Economics 11, 53-70.

Bernoth, K., von Hagen, J., 2003. The performance of the EURIBOR futures market: Efficiency and the impact of ECB policy announcements, Paper delivered at the Workshop "Monetary Policy and the Money Market, FED New York and ECB, 5-6 June.

Borio, C.E.V., Fritz, W., 1995. The response of short-term bank lending rates to policy rates: a cross-country perspective. In: BIS, 1995, Financial structure and the monetary transmission mechanism, CB Document 394, Basle, pp 106-153.

Chan, K.S., 1993. Consistency and limiting distribution of the least squares estimator of a threshold autoregressive model. The Annals of Statistics 21, 520-533.

Cole, S., Impson, M., Reichenstein, W., 1991. Do Treasury Bill futures rates satisfy rational expectation properties? Journal of Futures Markets 11, 591-601.

Cole, S., Reichenstein, W., 1994. Forecasting interest rates with Eurodollar futures rates. Journal of Futures Markets 14, 37-50.

Cottarelli, C., Ferri, G., Generale, A., 1995. Bank lending rates and financial structure in Italy: a case study. IMF Working Paper 95/38, Washington. 
Cottarelli, C., Kourelis, A., 1994. Financial structure, bank lending rates, and the transmission mechanism of monetary policy. IMF Staff Papers 41 No 4, Washington. de Bondt, G., 2002. Retail bank interest pass-through: new evidence at the euro area level. ECB Working Paper 136, Frankurt.

de Bondt, G., Mojon, B., Valla, N., 2002. Interest rate setting by universal banks and the monetary policy transmission mechanism in the euro area. Mimeo.

Enders, W., Granger, C.W.J., 1998. Unit root tests and asymmetric adjustment with an example using the term structure of interest rates. Journal of Business and Economic Statistics 16 (3), 304-311.

Enders, W., Siklos, P.I., 2000. Cointegration and threshold adjustment. Mimeo.

Engle, R.F. Granger, C.W.J., 1987. Co-integration and error correction: Representation, estimation, and testing, Econometrica 55, 251-276.

Hannan, T.H., Berger, A.N., 1991. The rigidity of prices: Evidence from the banking industry. American Economic Review 81(4), 938-945.

Heinemann, F., Schüler, M., 2001. Integration benefits on EU retail credit markets Evidence from interest rate pass-through. Zentrum für Europäische Wirtschaftsforschung (ZEW), Mannheim.

Krehbiel, T., Adkins, L., 1994. Interest rate futures: Evidence on forecast power, expected premiums, and the unbiased expectations hypothesis. Journal of Futures Markets 14, 531-543.

Krueger, J.T., Kuttner, K., 1996. The Fed funds rate as a predictor of Federal Reserve policy. Journal of Futures Markets 16, 865-879. 
Kuttner, K.N., 2001. Monetary policy surprises and interest rates: Evidence from the Fed funds futures market, Journal of Monetary Economics 47(3), 523-544.

Mojon, B., 2000. Financial structure and the interest channel of the ECB monetary policy. ECB Working Paper No. 40, Frankfurt.

Sander, H., Kleimeier, S., 2000. Asymmetric adjustment of commercial bank interest rates in the euro area: implications for monetary policy. Paper presented at the University of Groningen's Conference on "Financial Structure, Bank Behaviour, and Monetary Policy in the EMU", Groningen, October 2000.

Sander, H., Kleimeier, S., 2002. Asymmetric adjustment of commercial bank interest rates in the Euro area: an empirical investigation into interest rate pass-through. Kredit und Kapital 35(2), 161-192.

Sander, H., Kleimeier, S., 2003. Convergence in European retail banking? What interest rate pass-through tells us about monetary policy transmission, competition and integration, Journal of International Money and Finance (forthcoming).

Scholnick, B., 1996. Asymmetric adjustment of commercial bank interest rates: evidence from Malaysia and Singapore. Journal of International Money and Finance 15, 485496.

Scholnick, B., 1999. Interest rate asymmetries in long-term loan and deposit markets. Journal of Financial Services Research 16(1), 5-26.

Sellon, G.H., 2002. The changing U.S. financial system: some implication for the monetary transmission mechanism. Federal Reserve Bank of Kansas City Economic Review, First Quarter, 5-35. 
Tong, H., 1983. Threshold models in non-linear time series. Lecture Notes in Statistics 21, Springer Verlag, Berlin.

Toolsema, L.A., Sturm, J.-E., de Haan, J., 2002. Convergence of pass-through from money market to lending rates in EMU countries: new Evidence. University of Groningen, February, mimeo. 
Figure 1: Expected, unexpected and realized monetary policy rates

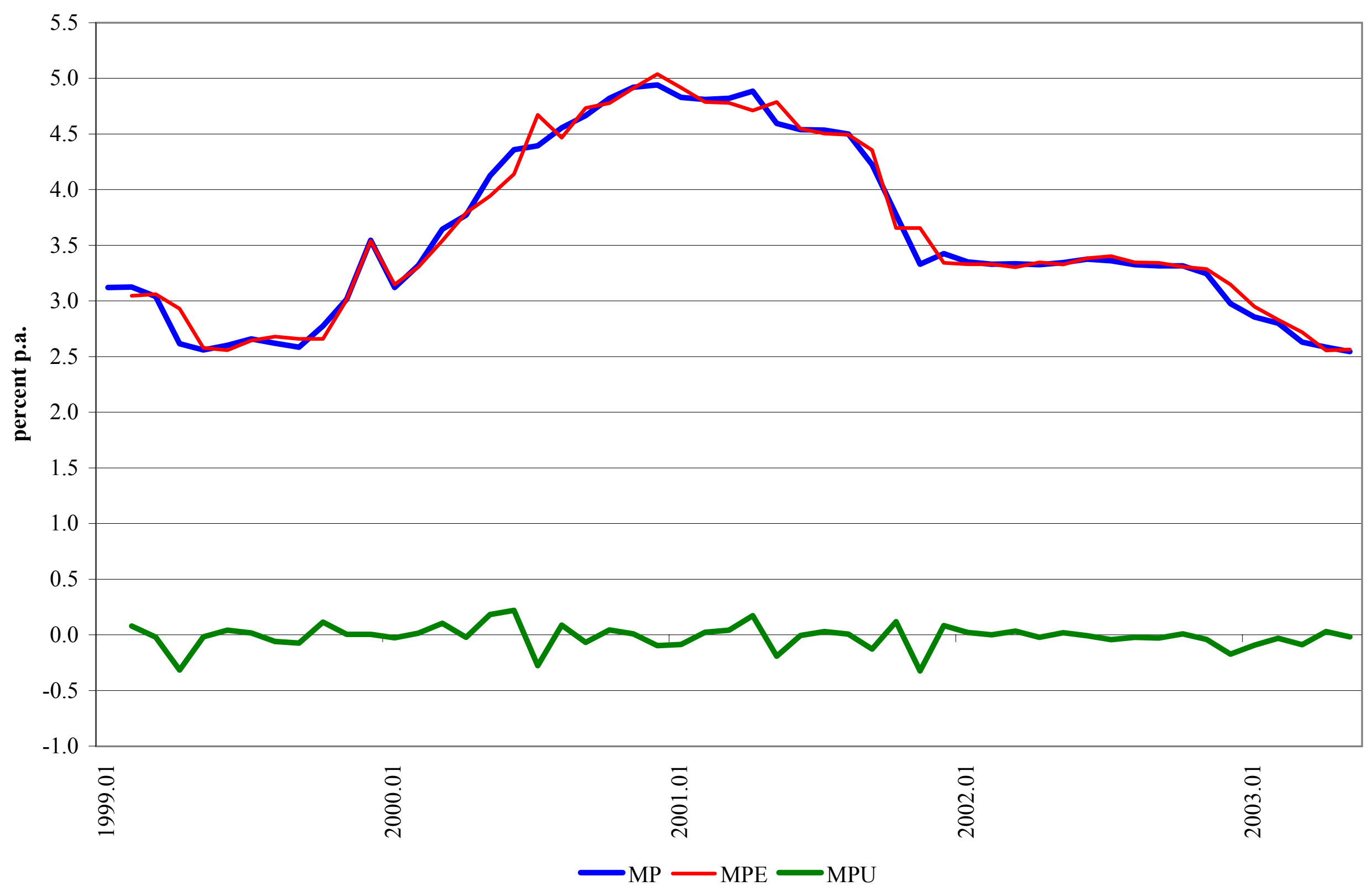




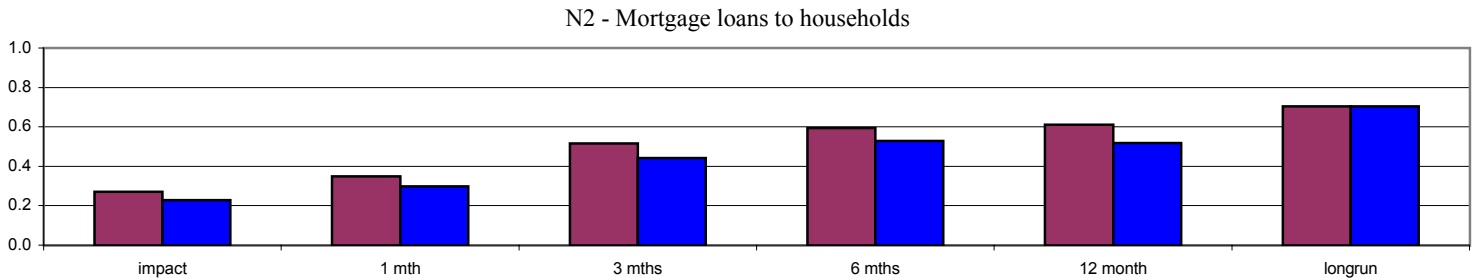

N3 - Consumer loans to households

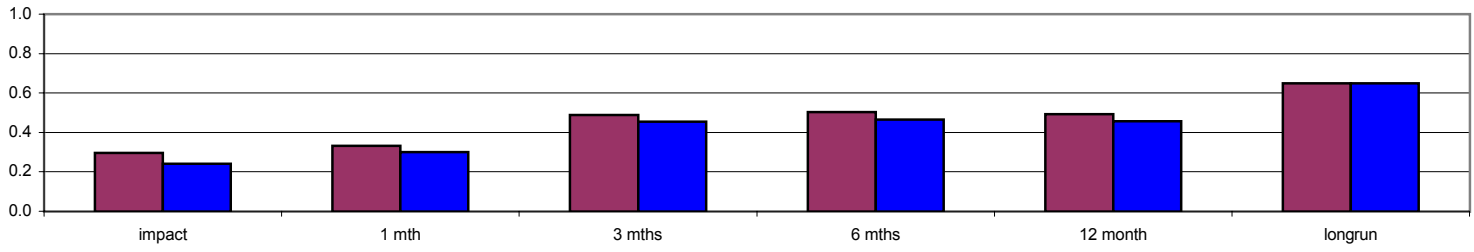

N4 - Short-term loans to enterprises

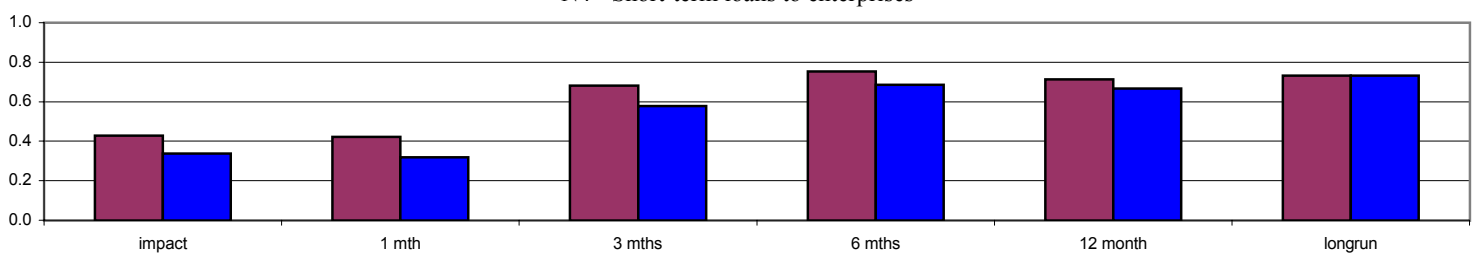

N5 - Medium and long-term loans to enterprises

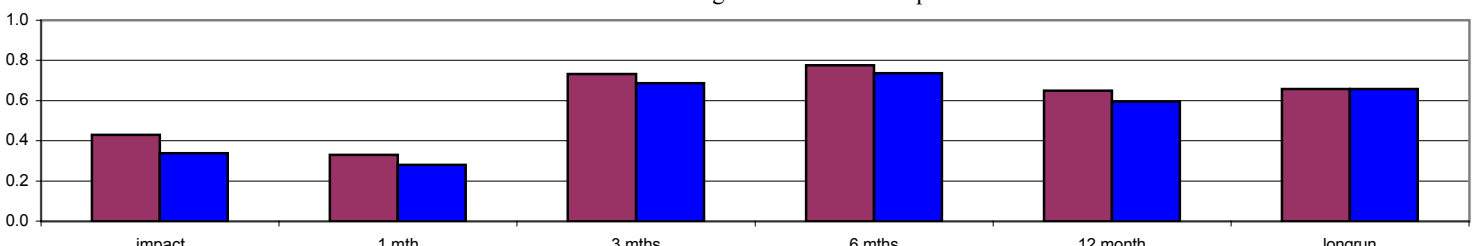

N7 - Current account deposits

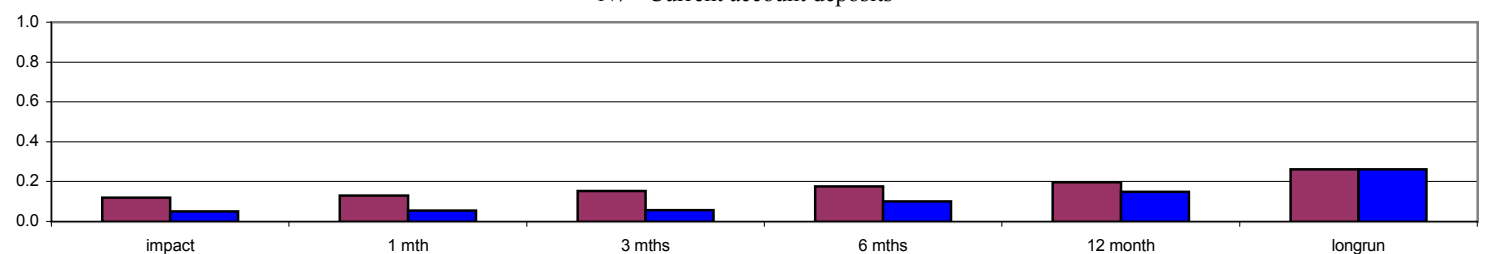

N8 - Time deposits

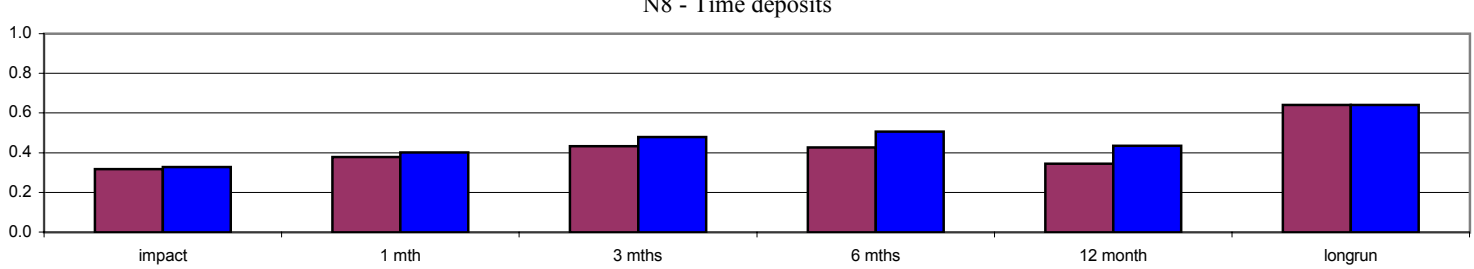

N9 - Savings accounts

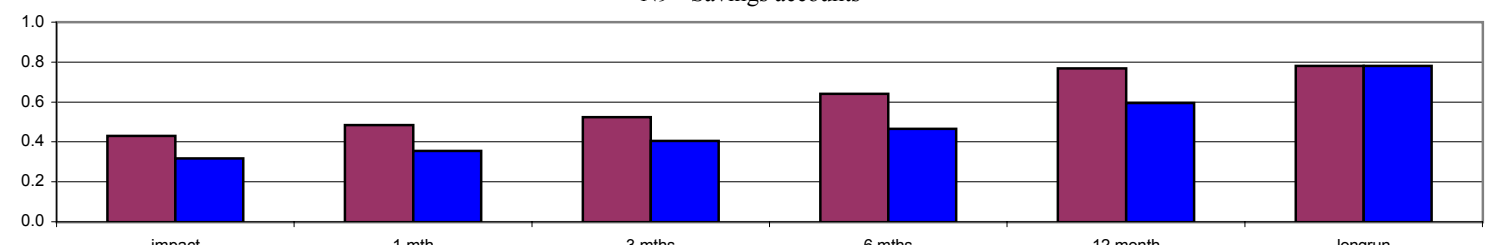

impact

$1 \mathrm{mth}$

3 mths

12 month

longrun

Note: The left bar represent average multipliers associated with a $+1 \%$ shock to the expected monetary policy rate whereas the right bar represent average multipliers associated with a $+1 \%$ shock to the unexpected MP rate. 


\begin{tabular}{|c|c|c|c|c|c|c|c|c|c|c|c|c|c|c|c|c|c|c|}
\hline \multirow[b]{3}{*}{ country } & \multirow[b]{3}{*}{ bankrate } & \multirow[b]{3}{*}{ model } & \\
\hline & & & \multicolumn{3}{|c|}{ impact } & \multicolumn{3}{|c|}{1 month } & & months & & & months & & & months & & longrun \\
\hline & & & both & MPE & $\overline{M P U}$ & both & MPE & $\overline{\text { MPU }}$ & both & MPE & $\overline{\mathrm{MPU}}$ & both & MPE & $\overline{M P U}$ & both & MPE & $\overline{\mathrm{MPU}}$ & \\
\hline Austria & 2 & MTAR* & 0.284 & 0.263 & 0.021 & 0.266 & 0.246 & 0.020 & 0.541 & 0.486 & 0.050 & 0.729 & 0.643 & 0.081 & 0.619 & 0.543 & 0.078 & $\overline{0.612}$ \\
\hline & 3 & TAR* & 0.359 & 0.315 & 0.044 & 0.382 & 0.336 & 0.046 & 0.556 & 0.489 & 0.070 & 0.668 & 0.587 & 0.084 & 0.661 & 0.581 & 0.080 & 0.611 \\
\hline & 4 & SYM & 0.343 & 0.314 & 0.029 & 0.486 & 0.437 & 0.048 & 0.714 & 0.636 & 0.078 & 0.749 & 0.659 & 0.090 & 0.605 & 0.531 & 0.074 & 0.625 \\
\hline & 7 & TAR* & 0.024 & 0.025 & -0.001 & 0.020 & 0.020 & 0.000 & 0.020 & 0.021 & -0.001 & 0.020 & 0.022 & -0.002 & 0.018 & 0.023 & -0.005 & 0.023 \\
\hline & 8 & SYM & 0.205 & 0.186 & 0.019 & 0.289 & 0.258 & 0.031 & 0.437 & 0.387 & 0.050 & 0.466 & 0.410 & 0.056 & 0.434 & 0.382 & 0.052 & 0.436 \\
\hline Belgium & 2 & BTAR* & 0.245 & 0.224 & 0.022 & 0.237 & 0.216 & 0.021 & 0.768 & 0.694 & 0.035 & 1.091 & 0.985 & 0.043 & 1.349 & 1.275 & 0.051 & 0.723 \\
\hline & 3 & STD & 0.452 & 0.407 & 0.044 & 0.464 & 0.418 & 0.046 & 0.464 & 0.418 & 0.046 & 0.464 & 0.418 & 0.046 & 0.464 & 0.418 & 0.046 & 0.854 \\
\hline & 4.1 & MTAR* & 0.517 & 0.460 & 0.057 & 0.527 & 0.468 & 0.058 & 0.863 & 0.841 & 0.109 & 1.126 & 1.060 & 0.142 & 1.014 & 0.874 & 0.122 & 0.925 \\
\hline & 4.2 & MTAR* & 0.428 & 0.364 & 0.063 & 0.377 & 0.321 & 0.056 & 0.584 & 0.504 & 0.080 & 0.717 & 0.624 & 0.092 & 0.827 & 0.726 & 0.101 & 0.853 \\
\hline & 5 & MTAR* & 0.254 & 0.213 & 0.041 & 0.316 & 0.265 & 0.051 & 0.447 & 0.382 & 0.065 & 0.475 & 0.415 & 0.060 & 0.305 & 0.272 & 0.033 & 0.344 \\
\hline & 8 & SYM & 0.290 & 0.227 & 0.063 & 0.303 & 0.232 & 0.071 & 0.273 & 0.196 & 0.077 & 0.150 & 0.072 & 0.079 & -0.300 & -0.369 & 0.069 & 0.832 \\
\hline & 9 & BTAR* & 0.001 & 0.003 & -0.002 & 0.001 & 0.003 & -0.002 & 0.001 & 0.004 & -0.002 & 0.001 & 0.004 & -0.002 & 0.001 & 0.004 & -0.002 & 0.024 \\
\hline Finland & 2 & STD & 0.453 & 0.415 & 0.038 & 0.572 & 0.524 & 0.048 & 0.612 & 0.561 & 0.051 & 0.615 & 0.563 & 0.052 & 0.615 & 0.563 & 0.052 & 1.069 \\
\hline & 3 & STD & 0.461 & 0.420 & 0.040 & 0.530 & 0.484 & 0.046 & 0.542 & 0.495 & 0.047 & 0.542 & 0.495 & 0.048 & 0.542 & 0.495 & 0.048 & 0.957 \\
\hline & 5 & BTAR* & 0.756 & 0.665 & 0.090 & 0.386 & 0.340 & 0.046 & 1.113 & 0.979 & 0.117 & 1.188 & 1.013 & 0.125 & 0.935 & 0.842 & 0.115 & 0.932 \\
\hline & 6 & SYM & 0.630 & 0.536 & 0.093 & 0.985 & 0.856 & 0.129 & 1.296 & 1.134 & 0.163 & 1.007 & 0.887 & 0.120 & 0.897 & 0.787 & 0.110 & 0.905 \\
\hline & 7 & BTAR* & 0.133 & 0.128 & 0.005 & 0.096 & 0.092 & 0.004 & 0.145 & 0.138 & 0.015 & 0.166 & 0.156 & 0.020 & 0.195 & 0.173 & 0.020 & 0.199 \\
\hline & 8 & MTAR* & -0.029 & -0.040 & 0.010 & -0.025 & -0.034 & 0.009 & -0.040 & -0.048 & 0.008 & -0.056 & -0.060 & 0.004 & -0.075 & -0.071 & -0.003 & -0.097 \\
\hline & 10 & MTAR* & 0.101 & 0.095 & 0.006 & 0.107 & 0.101 & 0.006 & 0.196 & 0.177 & 0.030 & 0.364 & 0.320 & 0.045 & 0.363 & 0.319 & 0.044 & 0.363 \\
\hline France & 4 & BTAR* & 0.526 & 0.481 & 0.045 & 0.285 & 0.261 & 0.024 & 1.218 & 1.071 & 0.085 & 1.064 & 0.991 & 0.112 & 0.670 & 0.594 & 0.096 & 0.788 \\
\hline & 5 & SYM & 0.244 & 0.228 & 0.016 & 0.351 & 0.318 & 0.033 & 0.527 & 0.472 & 0.056 & 0.661 & 0.585 & 0.076 & 0.717 & 0.631 & 0.086 & 0.716 \\
\hline & 8 & MTAR* & 0.913 & 0.821 & 0.092 & 0.909 & 0.818 & 0.091 & 1.153 & 1.023 & 0.131 & 1.100 & 0.965 & 0.135 & 0.939 & 0.825 & 0.114 & 0.984 \\
\hline & 9 & STD & 0.070 & 0.087 & -0.017 & 0.076 & 0.095 & -0.018 & 0.077 & 0.095 & -0.019 & 0.077 & 0.095 & -0.019 & 0.077 & 0.095 & -0.019 & -0.046 \\
\hline Germany & 2 & STD & 0.072 & 0.050 & 0.022 & 0.108 & 0.075 & 0.033 & 0.133 & 0.093 & 0.041 & 0.140 & 0.098 & 0.043 & 0.141 & 0.098 & 0.043 & 0.470 \\
\hline & 3 & STD & 0.125 & 0.106 & 0.019 & 0.160 & 0.136 & 0.024 & 0.172 & 0.146 & 0.026 & 0.173 & 0.147 & 0.026 & 0.173 & 0.147 & 0.026 & 0.383 \\
\hline & 4 & STD & 0.222 & 0.215 & 0.008 & 0.282 & 0.273 & 0.010 & 0.385 & 0.372 & 0.013 & 0.436 & 0.421 & 0.015 & 0.453 & 0.437 & 0.015 & 0.626 \\
\hline & 5 & MTAR* & 0.178 & 0.162 & 0.015 & 0.278 & 0.254 & 0.024 & 0.506 & 0.453 & 0.047 & 0.726 & 0.642 & 0.078 & 0.534 & 0.466 & 0.071 & 0.497 \\
\hline & 8.1 & MTAR* & 0.503 & 0.452 & 0.050 & 0.613 & 0.551 & 0.061 & 0.587 & 0.531 & 0.066 & 0.601 & 0.542 & 0.069 & 0.629 & 0.564 & 0.073 & 0.735 \\
\hline & 8.2 & SYM & 0.460 & 0.405 & 0.055 & 0.692 & 0.609 & 0.083 & 0.840 & 0.739 & 0.101 & 0.842 & 0.741 & 0.101 & 0.822 & 0.723 & 0.099 & 0.821 \\
\hline & 9.1 & TAR* & 0.118 & 0.106 & 0.013 & 0.150 & 0.134 & 0.016 & 0.184 & 0.165 & 0.019 & 0.140 & 0.127 & 0.013 & 0.040 & 0.041 & -0.001 & 0.273 \\
\hline & 9.2 & MTAR* & 0.213 & 0.181 & 0.032 & 0.309 & 0.262 & 0.047 & 0.342 & 0.288 & 0.054 & 0.293 & 0.243 & 0.050 & 0.216 & 0.173 & 0.043 & 0.759 \\
\hline Ireland & 1 & TAR* & 0.416 & 0.378 & 0.038 & 0.468 & 0.425 & 0.043 & 0.509 & 0.497 & 0.065 & 0.589 & 0.622 & 0.085 & 0.762 & 0.682 & 0.093 & 0.780 \\
\hline & 2 & MTAR* & 0.523 & 0.446 & 0.077 & 0.612 & 0.521 & 0.090 & 0.696 & 0.599 & 0.096 & 0.730 & 0.635 & 0.093 & 0.648 & 0.571 & 0.077 & 0.635 \\
\hline & 4 & TAR* & 0.421 & 0.380 & 0.041 & 0.453 & 0.408 & 0.044 & 0.467 & 0.450 & 0.059 & 0.482 & 0.538 & 0.073 & 0.619 & 0.600 & 0.082 & 0.699 \\
\hline & 5 & TAR* & 0.418 & 0.381 & 0.038 & 0.398 & 0.362 & 0.036 & 0.432 & 0.424 & 0.048 & 0.525 & 0.491 & 0.062 & 0.617 & 0.552 & 0.074 & 0.664 \\
\hline & 6 & SYM & 1.067 & 0.937 & 0.130 & 0.992 & 0.873 & 0.120 & 1.011 & 0.889 & 0.122 & 1.012 & 0.890 & 0.122 & 1.012 & 0.890 & 0.122 & 1.012 \\
\hline & 9.1 & BTAR* & 0.138 & 0.122 & 0.016 & 0.146 & 0.130 & 0.017 & 0.147 & 0.130 & 0.017 & 0.147 & 0.130 & 0.017 & 0.147 & 0.130 & 0.017 & 0.215 \\
\hline & 9.2 & BTAR* & 0.238 & 0.210 & 0.028 & 0.220 & 0.194 & 0.026 & 0.221 & 0.195 & 0.026 & 0.221 & 0.195 & 0.026 & 0.221 & 0.195 & 0.026 & 0.283 \\
\hline Italy & 2 & SYM & 0.146 & 0.122 & 0.024 & 0.410 & 0.357 & 0.053 & 0.599 & 0.526 & 0.073 & 0.553 & 0.485 & 0.067 & 0.604 & 0.531 & 0.073 & 0.604 \\
\hline & 4.1 & MTAR* & 0.250 & 0.244 & 0.006 & 0.290 & 0.283 & 0.007 & 0.462 & 0.432 & 0.038 & 0.638 & 0.567 & 0.076 & 0.635 & 0.556 & 0.078 & 0.623 \\
\hline & 4.2 & MTAR* & 0.253 & 0.252 & 0.001 & 0.369 & 0.367 & 0.001 & 0.470 & 0.462 & 0.033 & 0.713 & 0.648 & 0.083 & 0.840 & 0.736 & 0.104 & 0.811 \\
\hline & 5 & MTAR* & 0.582 & 0.520 & 0.062 & 0.353 & 0.316 & 0.038 & 1.155 & 1.018 & 0.128 & 0.984 & 0.864 & 0.122 & 0.711 & 0.627 & 0.082 & 0.723 \\
\hline & 7 & MTAR* & 0.192 & 0.186 & 0.006 & 0.260 & 0.252 & 0.009 & 0.234 & 0.234 & 0.020 & 0.309 & 0.289 & 0.036 & 0.398 & 0.353 & 0.048 & 0.419 \\
\hline & 8 & BTAR* & 0.328 & 0.303 & 0.025 & 0.430 & 0.397 & 0.033 & 0.400 & 0.377 & 0.023 & 0.288 & 0.291 & -0.002 & -0.122 & -0.027 & -0.095 & 0.641 \\
\hline & 10 & BTAR* & 0.169 & 0.164 & 0.005 & 0.233 & 0.226 & 0.007 & 0.268 & 0.263 & 0.005 & 0.264 & 0.266 & -0.002 & 0.226 & 0.248 & -0.022 & 0.348 \\
\hline Netherlands & 2 & MTAR* & 0.154 & 0.133 & 0.020 & 0.235 & 0.204 & 0.031 & 0.312 & 0.272 & 0.046 & 0.417 & 0.364 & 0.058 & 0.524 & 0.460 & 0.066 & 0.557 \\
\hline & 4 & TAR* & 0.806 & 0.719 & 0.087 & 0.465 & 0.415 & 0.050 & 0.738 & 0.657 & 0.081 & 0.883 & 0.784 & 0.100 & 0.948 & 0.837 & 0.110 & 0.983 \\
\hline & 7 & BTAR* & 0.004 & 0.003 & 0.001 & 0.003 & 0.003 & 0.001 & 0.001 & 0.000 & 0.001 & -0.004 & -0.004 & 0.000 & -0.015 & -0.014 & -0.001 & 0.038 \\
\hline & 8.1 & STD & 0.014 & -0.016 & 0.030 & 0.018 & -0.020 & 0.039 & 0.026 & -0.029 & 0.054 & 0.030 & -0.033 & 0.063 & 0.031 & -0.035 & 0.067 & 0.516 \\
\hline & 8.2 & STD & 0.117 & 0.084 & 0.033 & 0.156 & 0.111 & 0.044 & 0.173 & 0.123 & 0.049 & 0.175 & 0.125 & 0.050 & 0.175 & 0.125 & 0.050 & 0.556 \\
\hline Portugal & 2 & BTAR* & 0.336 & 0.317 & 0.019 & 0.349 & 0.329 & 0.020 & 0.512 & 0.463 & 0.028 & 0.596 & 0.533 & 0.032 & 0.627 & 0.558 & 0.034 & 0.826 \\
\hline & 3 & SYM & -0.121 & -0.080 & -0.042 & 0.220 & 0.197 & 0.024 & 0.335 & 0.298 & 0.038 & 0.413 & 0.365 & 0.048 & 0.453 & 0.398 & 0.054 & 0.455 \\
\hline & 4.1 & SYM & 0.141 & 0.126 & 0.015 & 0.201 & 0.178 & 0.023 & 0.360 & 0.318 & 0.042 & 0.444 & 0.391 & 0.053 & 0.387 & 0.340 & 0.047 & 0.379 \\
\hline & 4.2 & MTAR* & 0.458 & 0.416 & 0.042 & 0.307 & 0.279 & 0.028 & 0.720 & 0.638 & 0.082 & 0.737 & 0.646 & 0.091 & 0.615 & 0.541 & 0.074 & 0.629 \\
\hline & 8.1 & STD & 0.389 & 0.339 & 0.050 & 0.470 & 0.410 & 0.060 & 0.490 & 0.427 & 0.063 & 0.491 & 0.428 & 0.063 & 0.491 & 0.428 & 0.063 & 1.009 \\
\hline & 8.2 & SYM & 0.125 & 0.115 & 0.011 & 0.223 & 0.199 & 0.024 & 0.364 & 0.322 & 0.042 & 0.508 & 0.448 & 0.060 & 0.526 & 0.463 & 0.063 & 0.506 \\
\hline Spain & 2 & TAR* & 0.176 & 0.171 & 0.004 & 0.293 & 0.286 & 0.007 & 0.390 & 0.385 & 0.005 & 0.392 & 0.399 & -0.007 & 0.259 & 0.302 & -0.044 & 0.837 \\
\hline & 3 & MTAR* & 0.462 & 0.394 & 0.068 & 0.209 & 0.178 & 0.031 & 0.834 & 0.733 & 0.102 & 0.732 & 0.644 & 0.088 & 0.640 & 0.563 & 0.077 & 0.632 \\
\hline & 4 & SYM & 0.646 & 0.552 & 0.094 & 0.876 & 0.766 & 0.109 & 1.055 & 0.926 & 0.129 & 0.864 & 0.761 & 0.103 & 0.859 & 0.755 & 0.104 & 0.854 \\
\hline & 5 & MTAR* & 0.493 & 0.470 & 0.022 & 0.182 & 0.174 & 0.008 & 0.880 & 0.783 & 0.097 & 0.842 & 0.739 & 0.104 & 0.711 & 0.627 & 0.084 & 0.721 \\
\hline & 6 & SYM & 0.419 & 0.376 & 0.044 & 0.590 & 0.525 & 0.064 & 0.905 & 0.802 & 0.103 & 1.023 & 0.901 & 0.121 & 0.802 & 0.704 & 0.098 & 0.809 \\
\hline & 7 & STD & 0.203 & 0.185 & 0.018 & 0.224 & 0.204 & 0.019 & 0.306 & 0.280 & 0.027 & 0.345 & 0.315 & 0.030 & 0.355 & 0.324 & 0.031 & 0.625 \\
\hline & 8 & MTAR* & 0.508 & 0.472 & 0.037 & 0.494 & 0.458 & 0.036 & 0.557 & 0.508 & 0.052 & 0.643 & 0.576 & 0.069 & 0.720 & 0.637 & 0.084 & 0.758 \\
\hline & 10.1 & MTAR* & 0.649 & 0.571 & 0.078 & 0.626 & 0.551 & 0.075 & 0.880 & 0.774 & 0.106 & 1.091 & 0.959 & 0.131 & 0.998 & 0.866 & 0.119 & 1.002 \\
\hline & 10.2 & STD & 0.230 & 0.201 & 0.029 & 0.323 & 0.282 & 0.041 & 0.375 & 0.328 & 0.048 & 0.385 & 0.336 & 0.049 & 0.385 & 0.336 & 0.049 & 0.789 \\
\hline
\end{tabular}


Table 2: Multipliers for a $+1 \%$ shock in the monetary policy rate

\begin{tabular}{|c|c|c|c|c|c|c|c|}
\hline \multirow[b]{2}{*}{ country } & \multirow[b]{2}{*}{ bankrate } & \multicolumn{6}{|c|}{ multiplier } \\
\hline & & impact & 1 month & 3 months & 6 months & 12 months & longrun \\
\hline \multirow[t]{5}{*}{ Austria } & 2 & 0.26 & 0.34 & 0.74 & 0.69 & 0.63 & 0.61 \\
\hline & 3 & 0.41 & 0.55 & 0.72 & 0.71 & 0.59 & 0.61 \\
\hline & 4 & 0.34 & 0.55 & 0.68 & 0.63 & 0.62 & 0.63 \\
\hline & 7 & 0.01 & 0.03 & 0.03 & 0.03 & 0.03 & 0.02 \\
\hline & 8 & 0.20 & 0.31 & 0.40 & 0.43 & 0.44 & 0.44 \\
\hline \multirow[t]{7}{*}{ Belgium } & 2 & 0.22 & 0.22 & 0.73 & 1.20 & 1.42 & 0.72 \\
\hline & 3 & 0.43 & 0.45 & 0.46 & 0.46 & 0.46 & 0.46 \\
\hline & 4.1 & 0.49 & 0.51 & 0.82 & 1.10 & 1.03 & 0.92 \\
\hline & 4.2 & 0.50 & 0.63 & 0.72 & 0.78 & 0.83 & 0.85 \\
\hline & 5 & 0.28 & 0.34 & 0.47 & 0.48 & 0.30 & 0.34 \\
\hline & 8 & 0.43 & 0.45 & 0.43 & 0.39 & 0.32 & 0.83 \\
\hline & 9 & 0.00 & 0.00 & 0.00 & 0.00 & 0.00 & 0.02 \\
\hline \multirow[t]{7}{*}{ Finland } & 2 & 0.39 & 0.52 & 0.58 & 0.59 & 0.59 & 0.59 \\
\hline & 3 & 0.41 & 0.49 & 0.51 & 0.51 & 0.51 & 0.51 \\
\hline & 5 & 0.78 & 0.95 & 1.09 & 1.01 & 0.93 & 0.93 \\
\hline & 6 & 0.67 & 0.90 & 0.93 & 0.90 & 0.90 & 0.90 \\
\hline & 7 & 0.10 & 0.22 & 0.21 & 0.23 & 0.24 & 0.20 \\
\hline & 8 & -0.01 & -0.01 & -0.02 & -0.04 & -0.07 & -0.10 \\
\hline & 10 & 0.07 & 0.17 & 0.28 & 0.35 & 0.36 & 0.36 \\
\hline \multirow[t]{4}{*}{ France } & 4 & 0.45 & 0.67 & 1.06 & 0.80 & 0.78 & 0.79 \\
\hline & 5 & 0.29 & 0.38 & 0.52 & 0.63 & 0.70 & 0.72 \\
\hline & 8 & 0.94 & 1.19 & 1.26 & 0.97 & 0.96 & 0.98 \\
\hline & 9 & 0.03 & 0.03 & 0.03 & 0.03 & 0.03 & 0.03 \\
\hline \multirow[t]{8}{*}{ Germany } & 2 & 0.10 & 0.15 & 0.18 & 0.19 & 0.19 & 0.19 \\
\hline & 3 & 0.13 & 0.17 & 0.18 & 0.18 & 0.18 & 0.18 \\
\hline & 4 & 0.18 & 0.26 & 0.32 & 0.33 & 0.33 & 0.33 \\
\hline & 5 & 0.19 & 0.44 & 0.59 & 0.50 & 0.48 & 0.50 \\
\hline & 8.1 & 0.50 & 0.71 & 0.81 & 0.80 & 0.77 & 0.73 \\
\hline & 8.2 & 0.46 & 0.69 & 0.84 & 0.84 & 0.82 & 0.82 \\
\hline & 9.1 & 0.13 & 0.22 & 0.26 & 0.22 & 0.18 & 0.27 \\
\hline & 9.2 & 0.24 & 0.34 & 7.00 & 8.22 & 9.53 & 0.76 \\
\hline \multirow[t]{7}{*}{ Ireland } & 1 & 0.46 & 0.83 & 0.69 & 0.78 & 0.81 & 0.78 \\
\hline & 2 & 0.48 & 0.79 & 0.84 & 0.84 & 0.67 & 0.63 \\
\hline & 4 & 0.43 & 0.72 & 0.61 & 0.69 & 0.72 & 0.70 \\
\hline & 5 & 0.41 & 0.64 & 0.50 & 0.64 & 0.62 & 0.66 \\
\hline & 6 & 1.07 & 0.99 & 1.01 & 1.01 & 1.01 & 1.01 \\
\hline & 9.1 & 0.14 & 0.22 & 0.19 & 0.24 & 0.26 & 0.22 \\
\hline & 9.2 & 0.24 & 0.30 & 0.28 & 0.28 & 0.28 & 0.28 \\
\hline \multirow[t]{7}{*}{ Italy } & 2 & 0.17 & 0.40 & 0.56 & 0.60 & 0.60 & 0.60 \\
\hline & 4.1 & 0.17 & 0.45 & 0.60 & 0.69 & 0.63 & 0.62 \\
\hline & 4.2 & 0.17 & 0.49 & 0.79 & 0.83 & 0.81 & 0.81 \\
\hline & 5 & 0.64 & 0.77 & 1.05 & 0.65 & 0.75 & 0.72 \\
\hline & 7 & 0.13 & 0.34 & 0.42 & 0.47 & 0.44 & 0.42 \\
\hline & 8 & 0.29 & 0.53 & 0.53 & 0.49 & 0.36 & 0.64 \\
\hline & 10 & 0.12 & 0.32 & 0.35 & 0.35 & 0.35 & 0.35 \\
\hline \multirow[t]{5}{*}{ Netherlands } & 2 & 0.20 & 0.69 & 0.42 & 0.26 & 0.66 & 0.56 \\
\hline & 4 & 0.82 & 0.89 & 1.02 & 0.98 & 0.98 & 0.98 \\
\hline & 7 & 0.00 & 0.00 & 0.00 & 0.00 & -0.01 & 0.04 \\
\hline & 8.1 & 0.18 & 0.22 & 0.23 & 0.23 & 0.23 & 0.23 \\
\hline & 8.2 & 0.16 & 0.21 & 0.22 & 0.22 & 0.22 & 0.22 \\
\hline \multirow[t]{6}{*}{ Portugal } & 2 & 0.28 & 0.70 & 0.92 & 0.97 & 0.93 & 0.83 \\
\hline & 3 & -0.15 & 0.22 & 0.34 & 0.41 & 0.45 & 0.46 \\
\hline & 4.1 & 0.14 & 0.19 & 0.25 & 0.31 & 0.36 & 0.38 \\
\hline & 4.2 & 0.43 & 0.29 & 0.72 & 0.75 & 0.61 & 0.63 \\
\hline & 8.1 & 0.40 & 0.48 & 0.49 & 0.50 & 0.50 & 0.50 \\
\hline & 8.2 & 0.15 & 0.25 & 0.38 & 0.46 & 0.50 & 0.51 \\
\hline Spain & 2 & 0.17 & 0.44 & 0.80 & 0.62 & 0.50 & 0.84 \\
\hline & 3 & 0.35 & 0.72 & 0.74 & 0.61 & 0.63 & 0.63 \\
\hline & 4 & 0.81 & 0.83 & 0.85 & 0.85 & 0.85 & 0.85 \\
\hline & 5 & 0.36 & 0.54 & 0.88 & 0.74 & 0.73 & 0.72 \\
\hline & 6 & 0.41 & 0.60 & 0.74 & 0.79 & 0.81 & 0.81 \\
\hline & 7 & 0.20 & 0.27 & 0.30 & 0.30 & 0.30 & 0.30 \\
\hline & 8 & 0.47 & 0.80 & 0.89 & 0.80 & 0.77 & 0.76 \\
\hline & 10.1 & 0.76 & 0.87 & 1.01 & 1.00 & 1.00 & 1.00 \\
\hline & 10.2 & 0.24 & 0.33 & 0.38 & 0.39 & 0.39 & 0.39 \\
\hline
\end{tabular}


Table 3: Asymmetries in the pass-through

\begin{tabular}{|c|c|c|c|c|c|c|c|c|c|c|c|c|c|c|c|c|c|c|c|c|}
\hline \multirow{2}{*}{$\begin{array}{ll} & \text { dependent variable } \\
\text { independent variables } & \end{array}$} & \multicolumn{20}{|c|}{ multipliers } \\
\hline & impact & $1 \mathrm{mth}$ & $3 \mathrm{mth}$ & $6 \mathrm{mths}$ & 12mths & impact & $1 \mathrm{mth}$ & $3 \mathrm{mth}$ & $6 \mathrm{mths}$ & $12 \mathrm{mths}$ & impact & $1 \mathrm{mth}$ & $3 \mathrm{mth}$ & $6 \mathrm{mths}$ & $12 \mathrm{mths}$ & impact & $1 \mathrm{mth}$ & $3 \mathrm{mth}$ & 6 mths & $12 \mathrm{mths}$ \\
\hline constant & $\begin{array}{r}0.280 \\
13.499\end{array}$ & $\begin{array}{r}0.309 \\
15.255\end{array}$ & $\begin{array}{l}0.557 \\
6.494\end{array}$ & $\begin{array}{r}0.532 \\
18.847\end{array}$ & $\begin{array}{r}0.526 \\
10.147\end{array}$ & $\begin{array}{l}0.439 \\
6.419\end{array}$ & $\begin{array}{l}0.524 \\
7.944\end{array}$ & $\begin{array}{l}0.651 \\
1.984\end{array}$ & $\begin{array}{l}0.851 \\
9.020\end{array}$ & $\begin{array}{l}0.683 \\
3.425\end{array}$ & $\begin{array}{r}0.304 \\
14.479\end{array}$ & $\begin{array}{r}0.331 \\
16.190\end{array}$ & $\begin{array}{l}0.667 \\
7.839\end{array}$ & $\begin{array}{r}0.558 \\
19.666\end{array}$ & $\begin{array}{r}0.584 \\
11.390\end{array}$ & $\begin{array}{l}0.461 \\
6.662\end{array}$ & $\begin{array}{l}0.545 \\
8.146\end{array}$ & $\begin{array}{c}0.773 \\
2.386\end{array}$ & $\begin{array}{l}0.876 \\
9.259\end{array}$ & $\begin{array}{l}0.746 \\
3.779\end{array}$ \\
\hline expected shock dummy * deposit dummy & $\begin{array}{l}-0.043 \\
-1.132\end{array}$ & $\begin{array}{l}-0.033 \\
-0.896\end{array}$ & $\begin{array}{l}-0.032 \\
-0.203\end{array}$ & $\begin{array}{l}-0.176 \\
-3.384\end{array}$ & $\begin{array}{c}-0.128 \\
-1.334\end{array}$ & $\begin{array}{c}-0.009 \\
-0.243\end{array}$ & $\begin{array}{c}-0.024 \\
-0.667\end{array}$ & $\begin{array}{c}-0.072 \\
-0.399\end{array}$ & $\begin{array}{l}-0.058 \\
-1.112\end{array}$ & $\begin{array}{l}-0.062 \\
-0.561\end{array}$ & & & & & & & & & & \\
\hline expected shock dummy * loan dummy & $\begin{array}{l}0.112 \\
3.286\end{array}$ & $\begin{array}{l}0.100 \\
3.012\end{array}$ & $\begin{array}{c}0.095 \\
0.673\end{array}$ & $\begin{array}{l}0.170 \\
3.654\end{array}$ & $\begin{array}{l}0.131 \\
1.534\end{array}$ & $\begin{array}{l}0.088 \\
2.742\end{array}$ & $\begin{array}{l}0.094 \\
3.033\end{array}$ & $\begin{array}{l}0.123 \\
0.804\end{array}$ & $\begin{array}{l}0.086 \\
1.935\end{array}$ & $\begin{array}{l}0.084 \\
0.900\end{array}$ & & & & & & & & & & \\
\hline positive shock dummy * deposit dummy & & & & & & & & & & & $\begin{array}{l}-0.079 \\
-2.042\end{array}$ & $\begin{array}{l}-0.066 \\
-1.755\end{array}$ & $\begin{array}{l}-0.352 \\
-2.242\end{array}$ & $\begin{array}{l}-0.221 \\
-4.215\end{array}$ & $\begin{array}{l}-0.288 \\
-3.045\end{array}$ & $\begin{array}{r}-0.035 \\
-0.928\end{array}$ & $\begin{array}{r}-0.047 \\
-1.286\end{array}$ & $\begin{array}{l}-0.472 \\
-2.648\end{array}$ & $\begin{array}{l}-0.096 \\
-1.846\end{array}$ & $\begin{array}{l}-0.258 \\
-2.369\end{array}$ \\
\hline positive shock dummy * loan dummy & & & & & & & & & & & $\begin{array}{l}0.056 \\
1.626\end{array}$ & $\begin{array}{l}0.047 \\
1.398\end{array}$ & $\begin{array}{l}-0.052 \\
-0.375\end{array}$ & $\begin{array}{l}0.112 \\
2.409\end{array}$ & $\begin{array}{l}0.047 \\
0.551\end{array}$ & $\begin{array}{l}0.025 \\
0.775\end{array}$ & $\begin{array}{l}0.034 \\
1.075\end{array}$ & $\begin{array}{l}0.033 \\
0.218\end{array}$ & $\begin{array}{l}0.024 \\
0.542\end{array}$ & $\begin{array}{l}0.025 \\
0.268\end{array}$ \\
\hline $\mathrm{N} 2$ - mortgage loans to households & & & & & & $\begin{array}{l}-0.144 \\
-2.688\end{array}$ & $\begin{array}{l}-0.175 \\
-3.395\end{array}$ & $\begin{array}{c}-0.277 \\
-1.081\end{array}$ & $\begin{array}{l}-0.167 \\
-2.260\end{array}$ & $\begin{array}{l}-0.168 \\
-1.080\end{array}$ & & & & & & $\begin{array}{l}-0.135 \\
-2.484\end{array}$ & $\begin{array}{l}-0.166 \\
-3.169\end{array}$ & $\begin{array}{c}-0.356 \\
-1.405\end{array}$ & $\begin{array}{l}-0.161 \\
-2.175\end{array}$ & $\begin{array}{l}-0.203 \\
-1.315\end{array}$ \\
\hline N3 - consumer loans to households & & & & & & $\begin{array}{l}-0.115 \\
-1.933\end{array}$ & $\begin{array}{c}-0.184 \\
-3.193\end{array}$ & $\begin{array}{l}-0.342 \\
-1.195\end{array}$ & $\begin{array}{c}-0.254 \\
-3.083\end{array}$ & $\begin{array}{l}-0.275 \\
-1.583\end{array}$ & & & & & & $\begin{array}{c}-0.106 \\
-1.753\end{array}$ & $\begin{array}{l}-0.174 \\
-2.985\end{array}$ & $\begin{array}{r}-0.423 \\
-1.495\end{array}$ & $\begin{array}{c}-0.248 \\
-3.002\end{array}$ & $\begin{array}{l}-0.311 \\
-1.804\end{array}$ \\
\hline N4 - short-term loans to enterprises & & & & & & $\begin{array}{l}0.005 \\
0.088\end{array}$ & $\begin{array}{l}-0.122 \\
-2.406\end{array}$ & $\begin{array}{c}-0.068 \\
-0.270\end{array}$ & $\begin{array}{l}0.022 \\
0.307\end{array}$ & $\begin{array}{l}0.000 \\
0.001\end{array}$ & & & & & & $\begin{array}{c}0.014 \\
0.263\end{array}$ & $\begin{array}{c}-0.112 \\
-2.188\end{array}$ & $\begin{array}{c}-0.147 \\
-0.593\end{array}$ & $\begin{array}{l}0.028 \\
0.388\end{array}$ & $\begin{array}{l}-0.035 \\
-0.231\end{array}$ \\
\hline N5 - medium and long-term loans to enterprises & & & & & & $\begin{array}{c}-0.058 \\
-1.040\end{array}$ & $\begin{array}{l}-0.239 \\
-4.433\end{array}$ & $\begin{array}{r}-0.044 \\
-0.166\end{array}$ & $\begin{array}{l}0.015 \\
0.200\end{array}$ & $\begin{array}{l}-0.076 \\
-0.469\end{array}$ & & & & & & $\begin{array}{l}-0.049 \\
-0.865\end{array}$ & $\begin{array}{l}-0.230 \\
-4.202\end{array}$ & $\begin{array}{c}-0.122 \\
-0.461\end{array}$ & $\begin{array}{l}0.021 \\
0.275\end{array}$ & $\begin{array}{r}-0.111 \\
-0.686\end{array}$ \\
\hline N7 - current account deposits & & & & & & $\begin{array}{l}-0.252 \\
-4.094\end{array}$ & $\begin{array}{l}-0.318 \\
-5.339\end{array}$ & $\begin{array}{r}-0.534 \\
-1.806\end{array}$ & $\begin{array}{r}-0.493 \\
-5.793\end{array}$ & $\begin{array}{l}-0.448 \\
-2.491\end{array}$ & & & & & & $\begin{array}{l}-0.261 \\
-4.177\end{array}$ & $\begin{array}{l}-0.326 \\
-5.405\end{array}$ & $\begin{array}{r}-0.463 \\
-1.586\end{array}$ & $\begin{array}{l}-0.498 \\
-5.839\end{array}$ & $\begin{array}{l}-0.416 \\
-2.338\end{array}$ \\
\hline N8 - time deposits & & & & & & $\begin{array}{l}0.004 \\
0.078\end{array}$ & $\begin{array}{c}-0.028 \\
-0.547\end{array}$ & $\begin{array}{c}-0.228 \\
-0.902\end{array}$ & $\begin{array}{l}-0.178 \\
-2.438\end{array}$ & $\begin{array}{l}-0.275 \\
-1.785\end{array}$ & & & & & & $\begin{array}{l}-0.005 \\
-0.087\end{array}$ & $\begin{array}{c}-0.037 \\
-0.710\end{array}$ & $\begin{array}{c}-0.154 \\
-0.617\end{array}$ & $\begin{array}{l}-0.183 \\
-2.507\end{array}$ & $\begin{array}{r}-0.242 \\
-1.587\end{array}$ \\
\hline N9 - savings accounts & & & & & & $\begin{array}{r}-0.303 \\
-4.886\end{array}$ & $\begin{array}{c}-0.390 \\
-6.527\end{array}$ & $\begin{array}{l}0.367 \\
1.234\end{array}$ & $\begin{array}{l}-0.458 \\
-5.355\end{array}$ & $\begin{array}{l}-0.090 \\
-0.500\end{array}$ & & & & & & $\begin{array}{l}-0.313 \\
-4.986\end{array}$ & $\begin{array}{r}-0.401 \\
-6.604\end{array}$ & $\begin{array}{l}0.453 \\
1.542\end{array}$ & $\begin{array}{c}-0.464 \\
-5.414\end{array}$ & $\begin{array}{l}-0.052 \\
-0.293\end{array}$ \\
\hline Austria & & & & & & $\begin{array}{l}-0.145 \\
-2.030\end{array}$ & $\begin{array}{l}-0.114 \\
-1.663\end{array}$ & $\begin{array}{l}0.052 \\
0.153\end{array}$ & $\begin{array}{l}-0.128 \\
-1.305\end{array}$ & $\begin{array}{l}0.003 \\
0.017\end{array}$ & & & & & & $\begin{array}{l}-0.145 \\
-2.011\end{array}$ & $\begin{array}{r}-0.115 \\
-1.646\end{array}$ & $\begin{array}{l}0.056 \\
0.167\end{array}$ & $\begin{array}{c}-0.129 \\
-1.304\end{array}$ & $\begin{array}{l}0.005 \\
0.025\end{array}$ \\
\hline Belgium & & & & & & $\begin{array}{l}-0.057 \\
-0.890\end{array}$ & $\begin{array}{c}-0.040 \\
-0.647\end{array}$ & $\begin{array}{c}-0.102 \\
-0.331\end{array}$ & $\begin{array}{l}-0.162 \\
-1.831\end{array}$ & $\begin{array}{l}-0.064 \\
-0.341\end{array}$ & & & & & & $\begin{array}{l}-0.057 \\
-0.881\end{array}$ & $\begin{array}{c}-0.040 \\
-0.641\end{array}$ & $\begin{array}{l}-0.101 \\
-0.331\end{array}$ & $\begin{array}{l}-0.162 \\
-1.827\end{array}$ & $\begin{array}{l}-0.063 \\
-0.342\end{array}$ \\
\hline Finland & & & & & & $\begin{array}{l}-0.032 \\
-0.484\end{array}$ & $\begin{array}{c}-0.048 \\
-0.744\end{array}$ & $\begin{array}{l}0.079 \\
0.245\end{array}$ & $\begin{array}{l}-0.181 \\
-1.958\end{array}$ & $\begin{array}{l}-0.041 \\
-0.211\end{array}$ & & & & & & $\begin{array}{c}-0.033 \\
-0.483\end{array}$ & $\begin{array}{r}-0.048 \\
-0.738\end{array}$ & $\begin{array}{l}0.082 \\
0.257\end{array}$ & $\begin{array}{l}-0.181 \\
-1.955\end{array}$ & $\begin{array}{l}-0.040 \\
-0.207\end{array}$ \\
\hline Germany & & & & & & $\begin{array}{l}-0.115 \\
-1.835\end{array}$ & $\begin{array}{l}-0.030 \\
-0.495\end{array}$ & $\begin{array}{l}0.441 \\
1.471\end{array}$ & $\begin{array}{l}-0.183 \\
-2.122\end{array}$ & $\begin{array}{l}0.205 \\
1.124\end{array}$ & & & & & & $\begin{array}{l}-0.115 \\
-1.813\end{array}$ & $\begin{array}{l}-0.030 \\
-0.489\end{array}$ & $\begin{array}{l}0.441 \\
1.491\end{array}$ & $\begin{array}{c}-0.183 \\
-2.116\end{array}$ & $\begin{array}{l}0.205 \\
1.135\end{array}$ \\
\hline Ireland & & & & & & $\begin{array}{l}0.096 \\
1.463\end{array}$ & $\begin{array}{l}0.093 \\
1.480\end{array}$ & $\begin{array}{c}-0.228 \\
-0.729\end{array}$ & $\begin{array}{l}-0.180 \\
-2.004\end{array}$ & $\begin{array}{l}-0.082 \\
-0.428\end{array}$ & & & & & & $\begin{array}{l}0.098 \\
1.487\end{array}$ & $\begin{array}{l}0.096 \\
1.503\end{array}$ & $\begin{array}{c}-0.252 \\
-0.814\end{array}$ & $\begin{array}{l}-0.179 \\
-1.979\end{array}$ & $\begin{array}{l}-0.092 \\
-0.487\end{array}$ \\
\hline Italy & & & & & & $\begin{array}{l}-0.177 \\
-2.705\end{array}$ & $\begin{array}{r}-0.137 \\
-2.167\end{array}$ & $\begin{array}{c}-0.042 \\
-0.134\end{array}$ & $\begin{array}{r}-0.259 \\
-2.870\end{array}$ & $\begin{array}{l}-0.150 \\
-0.786\end{array}$ & & & & & & $\begin{array}{l}-0.179 \\
-2.696\end{array}$ & $\begin{array}{l}-0.139 \\
-2.163\end{array}$ & $\begin{array}{c}-0.028 \\
-0.091\end{array}$ & $\begin{array}{l}-0.260 \\
-2.874\end{array}$ & $\begin{array}{l}-0.144 \\
-0.761\end{array}$ \\
\hline Netherlands & & & & & & $\begin{array}{c}-0.130 \\
-1.831\end{array}$ & $\begin{array}{l}-0.184 \\
-2.686\end{array}$ & $\begin{array}{r}-0.057 \\
-0.167\end{array}$ & $\begin{array}{l}-0.262 \\
-2.684\end{array}$ & $\begin{array}{l}-0.032 \\
-0.157\end{array}$ & & & & & & $\begin{array}{l}-0.130 \\
-1.815\end{array}$ & $\begin{array}{l}-0.184 \\
-2.655\end{array}$ & $\begin{array}{r}-0.053 \\
-0.157\end{array}$ & $\begin{array}{l}-0.262 \\
-2.679\end{array}$ & $\begin{array}{l}-0.031 \\
-0.150\end{array}$ \\
\hline Portugal & & & & & & $\begin{array}{r}-0.244 \\
-3.596\end{array}$ & $\begin{array}{l}-0.167 \\
-2.554\end{array}$ & $\begin{array}{r}-0.021 \\
-0.064\end{array}$ & $\begin{array}{l}-0.198 \\
-2.115\end{array}$ & $\begin{array}{l}0.010 \\
0.049\end{array}$ & & & & & & $\begin{array}{l}-0.244 \\
-3.557\end{array}$ & $\begin{array}{l}-0.167 \\
-2.524\end{array}$ & $\begin{array}{l}-0.018 \\
-0.055\end{array}$ & $\begin{array}{l}-0.198 \\
-2.112\end{array}$ & $\begin{array}{l}0.011 \\
0.057\end{array}$ \\
\hline Spain & & & & & & $\begin{array}{r}-0.003 \\
-0.048\end{array}$ & $\begin{array}{l}-0.030 \\
-0.484\end{array}$ & $\begin{array}{l}0.165 \\
0.535\end{array}$ & $\begin{array}{r}-0.074 \\
-0.827\end{array}$ & $\begin{array}{l}0.047 \\
0.251\end{array}$ & & & & & & $\begin{array}{l}-0.004 \\
-0.067\end{array}$ & $\begin{array}{l}-0.031 \\
-0.498\end{array}$ & $\begin{array}{l}0.176 \\
0.578\end{array}$ & $\begin{array}{l}-0.074 \\
-0.834\end{array}$ & $\begin{array}{l}0.052 \\
0.280\end{array}$ \\
\hline $\begin{array}{l}\text { adjusted } R^{2} \\
\text { number of observations }\end{array}$ & $\begin{array}{r}5.2 \% \\
260 \\
\end{array}$ & $\begin{array}{r}4.1 \% \\
260 \\
\end{array}$ & $\begin{array}{r}-0.5 \% \\
260\end{array}$ & $\begin{array}{r}11.9 \% \\
260 \\
\end{array}$ & $\begin{array}{r}1.6 \% \\
260 \\
\end{array}$ & $\begin{array}{r}30.9 \% \\
260 \\
\end{array}$ & $\begin{array}{r}31.7 \% \\
260 \\
\end{array}$ & $\begin{array}{r}1.6 \% \\
260 \\
\end{array}$ & $\begin{array}{r}34.0 \% \\
260 \\
\end{array}$ & $\begin{array}{r}2.6 \% \\
260 \\
\end{array}$ & $\begin{array}{r}3.0 \% \\
260 \\
\end{array}$ & $\begin{array}{r}2.1 \% \\
260 \\
\end{array}$ & $\begin{array}{r}1.2 \% \\
260 \\
\end{array}$ & $\begin{array}{r}11.0 \% \\
260 \\
\end{array}$ & $\begin{array}{r}3.7 \% \\
260 \\
\end{array}$ & $\begin{array}{r}29.1 \% \\
260 \\
\end{array}$ & $\begin{array}{r}29.8 \% \\
260 \\
\end{array}$ & $\begin{array}{r}4.1 \% \\
260 \\
\end{array}$ & $\begin{array}{r}33.7 \% \\
260 \\
\end{array}$ & $\begin{array}{r}4.4 \% \\
260 \\
\end{array}$ \\
\hline
\end{tabular}

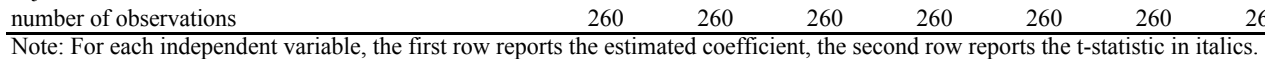


Table 4: Determinants of the pass-through

dependent variable

\begin{tabular}{|c|c|c|c|c|c|c|c|c|c|c|c|c|c|c|c|c|c|c|c|c|}
\hline \multirow[b]{2}{*}{ independent variables } & & \\
\hline & impact & $1 \mathrm{mth}$ & $3 \mathrm{mths}$ & $6 \mathrm{mths}$ & $12 \mathrm{mths}$ & impact & $1 \mathrm{mth}$ & 3 mths & $6 \mathrm{mths}$ & $12 \mathrm{mths}$ & impact & $1 \mathrm{mth}$ & $3 \mathrm{mths}$ & $6 \mathrm{mths}$ & $12 \mathrm{mths}$ & impact & $1 \mathrm{mth}$ & 3 mths & $6 \mathrm{mths}$ & $\overline{12 \mathrm{mths}}$ \\
\hline constant & $\begin{array}{l}0.280 \\
9.489\end{array}$ & $\begin{array}{r}0.309 \\
10.723\end{array}$ & $\begin{array}{r}0.467 \\
11.952\end{array}$ & $\begin{array}{r}0.516 \\
13.214\end{array}$ & $\begin{array}{r}0.477 \\
11.709\end{array}$ & $\begin{array}{l}0.439 \\
4.356\end{array}$ & $\begin{array}{l}0.524 \\
5.391\end{array}$ & $\begin{array}{l}0.802 \\
6.061\end{array}$ & $\begin{array}{l}0.863 \\
6.685\end{array}$ & $\begin{array}{l}0.762 \\
5.226\end{array}$ & $\begin{array}{l}0.280 \\
9.489\end{array}$ & $\begin{array}{r}0.309 \\
10.723\end{array}$ & $\begin{array}{l}0.647 \\
3.876\end{array}$ & $\begin{array}{r}0.547 \\
13.316\end{array}$ & $\begin{array}{l}0.575 \\
6.027\end{array}$ & $\begin{array}{l}0.439 \\
4.356\end{array}$ & $\begin{array}{l}0.524 \\
5.391\end{array}$ & $\begin{array}{l}0.499 \\
0.799\end{array}$ & $\begin{array}{l}0.839 \\
5.762\end{array}$ & $\begin{array}{l}0.603 \\
1.652\end{array}$ \\
\hline expected shock dummy * deposit dummy & $\begin{array}{r}-0.043 \\
-0.796\end{array}$ & $\begin{array}{c}-0.033 \\
-0.630\end{array}$ & $\begin{array}{l}-0.145 \\
-2.012\end{array}$ & $\begin{array}{l}-0.181 \\
-2.515\end{array}$ & $\begin{array}{l}-0.185 \\
-2.466\end{array}$ & $\begin{array}{c}-0.009 \\
-0.165\end{array}$ & $\begin{array}{c}-0.024 \\
-0.452\end{array}$ & $\begin{array}{c}-0.051 \\
-0.706\end{array}$ & $\begin{array}{c}-0.054 \\
-0.755\end{array}$ & $\begin{array}{l}-0.051 \\
-0.639\end{array}$ & $\begin{array}{r}-0.043 \\
-0.796\end{array}$ & $\begin{array}{c}-0.033 \\
-0.630\end{array}$ & $\begin{array}{l}0.081 \\
0.263\end{array}$ & $\begin{array}{l}-0.171 \\
-2.256\end{array}$ & $\begin{array}{l}-0.070 \\
-0.397\end{array}$ & $\begin{array}{c}-0.009 \\
-0.165\end{array}$ & $\begin{array}{c}-0.024 \\
-0.452\end{array}$ & $\begin{array}{c}-0.093 \\
-0.269\end{array}$ & $\begin{array}{c}-0.062 \\
-0.771\end{array}$ & $\begin{array}{c}-0.072 \\
-0.358\end{array}$ \\
\hline expected shock dummy * loan dummy & $\begin{array}{l}0.112 \\
2.310\end{array}$ & $\begin{array}{l}0.100 \\
2.117\end{array}$ & $\begin{array}{l}0.181 \\
2.806\end{array}$ & $\begin{array}{c}0.181 \\
2.821\end{array}$ & $\begin{array}{l}0.182 \\
2.708\end{array}$ & $\begin{array}{l}0.088 \\
1.861\end{array}$ & $\begin{array}{c}0.094 \\
2.059\end{array}$ & $\begin{array}{l}0.114 \\
1.839\end{array}$ & $\begin{array}{l}0.091 \\
1.500\end{array}$ & $\begin{array}{l}0.086 \\
1.264\end{array}$ & $\begin{array}{l}0.112 \\
2.310\end{array}$ & $\begin{array}{l}0.100 \\
2.117\end{array}$ & $\begin{array}{l}0.010 \\
0.035\end{array}$ & $\begin{array}{l}0.158 \\
2.336\end{array}$ & $\begin{array}{l}0.080 \\
0.511\end{array}$ & $\begin{array}{l}0.088 \\
1.861\end{array}$ & $\begin{array}{c}0.094 \\
2.059\end{array}$ & $\begin{array}{l}0.133 \\
0.454\end{array}$ & $\begin{array}{l}0.080 \\
1.178\end{array}$ & $\begin{array}{l}0.082 \\
0.478\end{array}$ \\
\hline N2 - mortgage loans to households & & & & & & $\begin{array}{l}-0.144 \\
-1.824\end{array}$ & $\begin{array}{l}-0.175 \\
-2.304\end{array}$ & $\begin{array}{c}-0.151 \\
-1.457\end{array}$ & $\begin{array}{c}-0.136 \\
-1.349\end{array}$ & $\begin{array}{l}-0.096 \\
-0.840\end{array}$ & & & & & & $\begin{array}{l}-0.144 \\
-1.824\end{array}$ & $\begin{array}{l}-0.175 \\
-2.304\end{array}$ & $\begin{array}{c}-0.404 \\
-0.826\end{array}$ & $\begin{array}{c}-0.197 \\
-1.733\end{array}$ & $\begin{array}{r}-0.241 \\
-0.844\end{array}$ \\
\hline $\mathrm{N} 3$ - consumer loans to households & & & & & & $\begin{array}{l}-0.115 \\
-1.312\end{array}$ & $\begin{array}{l}-0.184 \\
-2.167\end{array}$ & $\begin{array}{r}-0.183 \\
-1.587\end{array}$ & $\begin{array}{c}-0.245 \\
-2.171\end{array}$ & $\begin{array}{l}-0.203 \\
-1.592\end{array}$ & & & & & & $\begin{array}{l}-0.115 \\
-1.312\end{array}$ & $\begin{array}{l}-0.184 \\
-2.167\end{array}$ & $\begin{array}{l}-0.501 \\
-0.919\end{array}$ & $\begin{array}{c}-0.263 \\
-2.071\end{array}$ & $\begin{array}{c}-0.348 \\
-1.093\end{array}$ \\
\hline $\mathrm{N} 4$ - short-term loans to enterprises & & & & & & $\begin{array}{l}0.005 \\
0.060\end{array}$ & $\begin{array}{l}-0.122 \\
-1.633\end{array}$ & $\begin{array}{c}-0.004 \\
-0.035\end{array}$ & $\begin{array}{c}0.009 \\
0.089\end{array}$ & $\begin{array}{l}0.022 \\
0.193\end{array}$ & & & & & & $\begin{array}{l}0.005 \\
0.060\end{array}$ & $\begin{array}{l}-0.122 \\
-1.633\end{array}$ & $\begin{array}{c}-0.132 \\
-0.276\end{array}$ & $\begin{array}{l}0.036 \\
0.319\end{array}$ & $\begin{array}{c}-0.021 \\
-0.076\end{array}$ \\
\hline N5 - medium and long-term loans to enterprises & & & & & & $\begin{array}{r}-0.058 \\
-0.706\end{array}$ & $\begin{array}{c}-0.239 \\
-3.008\end{array}$ & $\begin{array}{l}0.023 \\
0.214\end{array}$ & $\begin{array}{l}0.016 \\
0.148\end{array}$ & $\begin{array}{l}-0.068 \\
-0.568\end{array}$ & & & & & & $\begin{array}{c}-0.058 \\
-0.706\end{array}$ & $\begin{array}{l}-0.239 \\
-3.008\end{array}$ & $\begin{array}{c}-0.112 \\
-0.219\end{array}$ & $\begin{array}{l}0.015 \\
0.129\end{array}$ & $\begin{array}{r}-0.085 \\
-0.286\end{array}$ \\
\hline N7 - current account deposits & & & & & & $\begin{array}{l}-0.252 \\
-2.778\end{array}$ & $\begin{array}{c}-0.318 \\
-3.623\end{array}$ & $\begin{array}{l}-0.454 \\
-3.803\end{array}$ & $\begin{array}{l}-0.485 \\
-4.167\end{array}$ & $\begin{array}{l}-0.399 \\
-3.036\end{array}$ & & & & & & $\begin{array}{l}-0.252 \\
-2.778\end{array}$ & $\begin{array}{l}-0.318 \\
-3.623\end{array}$ & $\begin{array}{l}-0.614 \\
-1.091\end{array}$ & $\begin{array}{l}-0.500 \\
-3.813\end{array}$ & $\begin{array}{r}-0.496 \\
-1.508\end{array}$ \\
\hline N8 - time deposits & & & & & & $\begin{array}{l}0.004 \\
0.053\end{array}$ & $\begin{array}{c}-0.028 \\
-0.371\end{array}$ & $\begin{array}{l}-0.090 \\
-0.879\end{array}$ & $\begin{array}{l}-0.161 \\
-1.620\end{array}$ & $\begin{array}{l}-0.200 \\
-1.776\end{array}$ & & & & & & $\begin{array}{l}0.004 \\
0.053\end{array}$ & $\begin{array}{l}-0.028 \\
-0.371\end{array}$ & $\begin{array}{l}-0.367 \\
-0.761\end{array}$ & $\begin{array}{c}-0.194 \\
-1.723\end{array}$ & $\begin{array}{c}-0.349 \\
-1.241\end{array}$ \\
\hline N9 - savings accounts & & & & & & $\begin{array}{l}-0.303 \\
-3.316\end{array}$ & $\begin{array}{l}-0.390 \\
-4.429\end{array}$ & $\begin{array}{c}-0.436 \\
-3.633\end{array}$ & $\begin{array}{l}-0.526 \\
-4.497\end{array}$ & $\begin{array}{l}-0.535 \\
-4.045\end{array}$ & & & & & & $\begin{array}{l}-0.303 \\
-3.316\end{array}$ & $\begin{array}{l}-0.390 \\
-4.429\end{array}$ & $\begin{array}{c}1.170 \\
2.065\end{array}$ & $\begin{array}{c}-0.389 \\
-2.952\end{array}$ & $\begin{array}{l}0.354 \\
1.071\end{array}$ \\
\hline Belgium & & & & & & $\begin{array}{l}-0.057 \\
-0.604\end{array}$ & $\begin{array}{c}-0.040 \\
-0.439\end{array}$ & $\begin{array}{c}-0.208 \\
-1.679\end{array}$ & $\begin{array}{c}-0.128 \\
-1.056\end{array}$ & $\begin{array}{l}-0.058 \\
-0.427\end{array}$ & & & & & & $\begin{array}{l}-0.057 \\
-0.604\end{array}$ & $\begin{array}{r}-0.040 \\
-0.439\end{array}$ & $\begin{array}{l}0.005 \\
0.008\end{array}$ & $\begin{array}{l}-0.196 \\
-1.437\end{array}$ & $\begin{array}{r}-0.069 \\
-0.202\end{array}$ \\
\hline Finland & & & & & & $\begin{array}{l}-0.032 \\
-0.329\end{array}$ & $\begin{array}{l}-0.048 \\
-0.505\end{array}$ & $\begin{array}{l}-0.167 \\
-1.284\end{array}$ & $\begin{array}{l}-0.205 \\
-1.622\end{array}$ & $\begin{array}{l}-0.160 \\
-1.121\end{array}$ & & & & & & $\begin{array}{l}-0.032 \\
-0.329\end{array}$ & $\begin{array}{l}-0.048 \\
-0.505\end{array}$ & $\begin{array}{l}0.324 \\
0.530\end{array}$ & $\begin{array}{l}-0.157 \\
-1.099\end{array}$ & $\begin{array}{l}0.078 \\
0.218\end{array}$ \\
\hline Germany & & & & & & $\begin{array}{l}-0.115 \\
-1.245\end{array}$ & $\begin{array}{r}-0.030 \\
-0.336\end{array}$ & $\begin{array}{c}-0.261 \\
-2.159\end{array}$ & $\begin{array}{l}-0.243 \\
-2.057\end{array}$ & $\begin{array}{l}-0.170 \\
-1.277\end{array}$ & & & & & & $\begin{array}{l}-0.115 \\
-1.245\end{array}$ & $\begin{array}{r}-0.030 \\
-0.336\end{array}$ & $\begin{array}{l}1.142 \\
2.001\end{array}$ & $\begin{array}{r}-0.123 \\
-0.926\end{array}$ & $\begin{array}{l}0.580 \\
1.739\end{array}$ \\
\hline Ireland & & & & & & $\begin{array}{l}0.096 \\
0.993\end{array}$ & $\begin{array}{l}0.093 \\
1.005\end{array}$ & $\begin{array}{r}-0.207 \\
-1.635\end{array}$ & $\begin{array}{c}-0.211 \\
-1.715\end{array}$ & $\begin{array}{l}-0.083 \\
-0.597\end{array}$ & & & & & & $\begin{array}{l}0.096 \\
0.993\end{array}$ & $\begin{array}{l}0.093 \\
1.005\end{array}$ & $\begin{array}{c}-0.250 \\
-0.419\end{array}$ & $\begin{array}{r}-0.149 \\
-1.076\end{array}$ & $\begin{array}{c}-0.080 \\
-0.229\end{array}$ \\
\hline Italy & & & & & & $\begin{array}{l}-0.177 \\
-1.836\end{array}$ & $\begin{array}{l}-0.137 \\
-1.471\end{array}$ & $\begin{array}{c}-0.292 \\
-2.305\end{array}$ & $\begin{array}{c}-0.293 \\
-2.372\end{array}$ & $\begin{array}{c}-0.268 \\
-1.921\end{array}$ & & & & & & $\begin{array}{l}-0.177 \\
-1.836\end{array}$ & $\begin{array}{l}-0.137 \\
-1.471\end{array}$ & $\begin{array}{l}0.208 \\
0.348\end{array}$ & $\begin{array}{l}-0.225 \\
-1.617\end{array}$ & $\begin{array}{c}-0.032 \\
-0.091\end{array}$ \\
\hline Netherlands & & & & & & $\begin{array}{l}-0.130 \\
-1.243\end{array}$ & $\begin{array}{l}-0.184 \\
-1.823\end{array}$ & $\begin{array}{l}-0.347 \\
-2.535\end{array}$ & $\begin{array}{l}-0.317 \\
-2.372\end{array}$ & $\begin{array}{c}-0.193 \\
-1.276\end{array}$ & & & & & & $\begin{array}{l}-0.130 \\
-1.243\end{array}$ & $\begin{array}{l}-0.184 \\
-1.823\end{array}$ & $\begin{array}{l}0.234 \\
0.362\end{array}$ & $\begin{array}{c}-0.207 \\
-1.374\end{array}$ & $\begin{array}{l}0.128 \\
0.338\end{array}$ \\
\hline Portugal & & & & & & $\begin{array}{l}-0.244 \\
-2.441\end{array}$ & $\begin{array}{l}-0.167 \\
-1.733\end{array}$ & $\begin{array}{r}-0.303 \\
-2.314\end{array}$ & $\begin{array}{r}-0.254 \\
-1.986\end{array}$ & $\begin{array}{c}-0.169 \\
-1.172\end{array}$ & & & & & & $\begin{array}{l}-0.244 \\
-2.441\end{array}$ & $\begin{array}{l}-0.167 \\
-1.733\end{array}$ & $\begin{array}{l}0.262 \\
0.423\end{array}$ & $\begin{array}{r}-0.141 \\
-0.980\end{array}$ & $\begin{array}{l}0.189 \\
0.523\end{array}$ \\
\hline Spain & & & & & & $\begin{array}{l}-0.003 \\
-0.033\end{array}$ & $\begin{array}{c}-0.030 \\
-0.328\end{array}$ & $\begin{array}{l}-0.070 \\
-0.564\end{array}$ & $\begin{array}{c}-0.093 \\
-0.762\end{array}$ & $\begin{array}{l}-0.068 \\
-0.495\end{array}$ & & & & & & $\begin{array}{l}-0.003 \\
-0.033\end{array}$ & $\begin{array}{l}-0.030 \\
-0.328\end{array}$ & $\begin{array}{c}0.401 \\
0.681\end{array}$ & $\begin{array}{l}-0.054 \\
-0.397\end{array}$ & $\begin{array}{c}0.162 \\
0.472\end{array}$ \\
\hline $\begin{array}{l}\text { adjusted } \mathrm{R}^{2} \\
\text { number of observations }\end{array}$ & $\begin{array}{r}4.5 \% \\
130\end{array}$ & $\begin{array}{r}3.3 \% \\
130\end{array}$ & $\begin{array}{r}10.7 \% \\
130\end{array}$ & $\begin{array}{r}13.0 \% \\
130\end{array}$ & $\begin{array}{r}12.2 \% \\
130\end{array}$ & $\begin{array}{r}25.2 \% \\
130\end{array}$ & $\begin{array}{r}26.1 \% \\
130\end{array}$ & $\begin{array}{r}31.5 \% \\
130\end{array}$ & $\begin{array}{r}36.4 \% \\
130\end{array}$ & $\begin{array}{r}24.6 \% \\
130\end{array}$ & $\begin{array}{r}4.5 \% \\
130\end{array}$ & $\begin{array}{r}3.3 \% \\
130\end{array}$ & $\begin{array}{r}-1.5 \% \\
130\end{array}$ & $\begin{array}{r}9.6 \% \\
130\end{array}$ & $\begin{array}{r}-1.1 \% \\
130\end{array}$ & $\begin{array}{r}25.2 \% \\
130\end{array}$ & $\begin{array}{r}26.1 \% \\
130\end{array}$ & $\begin{array}{r}4.8 \% \\
130\end{array}$ & $\begin{array}{r}24.0 \% \\
130\end{array}$ & $\begin{array}{r}1.1 \% \\
130\end{array}$ \\
\hline
\end{tabular}

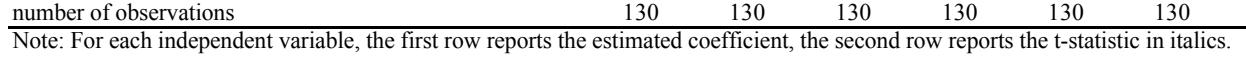


Table 5: Convergence in the pass-through

\begin{tabular}{|c|c|c|c|c|c|c|c|c|c|c|c|c|c|c|c|c|c|c|c|c|}
\hline \multirow[t]{2}{*}{ dependent variable } & \multicolumn{5}{|c|}{ multipliers for $+1 \%$ shock } & \multicolumn{15}{|c|}{ multipliers for $-1 \%$ shock } \\
\hline & impact & $1 \mathrm{mth}$ & $3 \mathrm{mths}$ & $6 \mathrm{mths}$ & $12 \mathrm{mths}$ & impact & $1 \mathrm{mth}$ & 3 mths & $6 \mathrm{mths}$ & $12 \mathrm{mths}$ & impact & $1 \mathrm{mth}$ & $3 \mathrm{mths}$ & $6 \mathrm{mths}$ & $12 \mathrm{mths}$ & impact & $1 \mathrm{mth}$ & $3 \mathrm{mths}$ & $6 \mathrm{mths}$ & $12 \mathrm{mths}$ \\
\hline constant & $\begin{array}{r}0.644 \\
10.691\end{array}$ & $\begin{array}{r}0.558 \\
10.501\end{array}$ & $\begin{array}{l}0.544 \\
9.592\end{array}$ & $\begin{array}{l}0.468 \\
8.848\end{array}$ & $\begin{array}{l}0.570 \\
8.445\end{array}$ & $\begin{array}{l}0.866 \\
3.781\end{array}$ & $\begin{array}{l}0.626 \\
3.208\end{array}$ & $\begin{array}{l}0.903 \\
4.605\end{array}$ & $\begin{array}{l}0.780 \\
4.069\end{array}$ & $\begin{array}{l}0.614 \\
2.579\end{array}$ & $\begin{array}{l}0.280 \\
9.489\end{array}$ & $\begin{array}{r}0.309 \\
10.723\end{array}$ & $\begin{array}{l}0.647 \\
3.876\end{array}$ & $\begin{array}{r}0.547 \\
13.316\end{array}$ & $\begin{array}{l}0.575 \\
6.027\end{array}$ & $\begin{array}{l}0.439 \\
4.356\end{array}$ & $\begin{array}{l}0.524 \\
5.391\end{array}$ & $\begin{array}{l}0.499 \\
0.799\end{array}$ & $\begin{array}{l}0.839 \\
5.762\end{array}$ & $\begin{array}{l}0.603 \\
1.652\end{array}$ \\
\hline expected shock dummy * deposit dummy & $\begin{array}{l}-0.029 \\
-0.258\end{array}$ & $\begin{array}{l}0.034 \\
0.349\end{array}$ & $\begin{array}{l}0.034 \\
0.323\end{array}$ & $\begin{array}{l}0.140 \\
1.431\end{array}$ & $\begin{array}{l}0.233 \\
1.871\end{array}$ & $\begin{array}{l}-0.088 \\
-0.700\end{array}$ & $\begin{array}{l}-0.102 \\
-0.944\end{array}$ & $\begin{array}{l}-0.114 \\
-1.060\end{array}$ & $\begin{array}{l}0.006 \\
0.058\end{array}$ & $\begin{array}{l}-0.057 \\
-0.432\end{array}$ & $\begin{array}{l}-0.043 \\
-0.796\end{array}$ & $\begin{array}{c}-0.033 \\
-0.630\end{array}$ & $\begin{array}{l}0.081 \\
0.263\end{array}$ & $\begin{array}{l}-0.171 \\
-2.256\end{array}$ & $\begin{array}{l}-0.070 \\
-0.397\end{array}$ & $\begin{array}{r}-0.009 \\
-0.165\end{array}$ & $\begin{array}{l}-0.024 \\
-0.452\end{array}$ & $\begin{array}{c}-0.093 \\
-0.269\end{array}$ & $\begin{array}{l}-0.062 \\
-0.771\end{array}$ & $\begin{array}{r}-0.072 \\
-0.358\end{array}$ \\
\hline expected shock dummy $*$ loan dummy & $\begin{array}{l}-0.231 \\
-2.327\end{array}$ & $\begin{array}{l}-0.267 \\
-3.053\end{array}$ & $\begin{array}{l}-0.245 \\
-2.627\end{array}$ & $\begin{array}{c}-0.229 \\
-2.630\end{array}$ & $\begin{array}{l}-0.342 \\
-3.076\end{array}$ & $\begin{array}{l}-0.188 \\
-1.756\end{array}$ & $\begin{array}{l}-0.171 \\
-1.864\end{array}$ & $\begin{array}{r}-0.140 \\
-1.524\end{array}$ & $\begin{array}{l}-0.134 \\
-1.490\end{array}$ & $\begin{array}{l}-0.136 \\
-1.219\end{array}$ & $\begin{array}{l}0.112 \\
2.310\end{array}$ & $\begin{array}{l}0.100 \\
2.117\end{array}$ & $\begin{array}{l}0.010 \\
0.035\end{array}$ & $\begin{array}{l}0.158 \\
2.336\end{array}$ & $\begin{array}{l}0.080 \\
0.511\end{array}$ & $\begin{array}{l}0.088 \\
1.861\end{array}$ & $\begin{array}{l}0.094 \\
2.059\end{array}$ & $\begin{array}{l}0.133 \\
0.454\end{array}$ & $\begin{array}{l}0.080 \\
1.178\end{array}$ & $\begin{array}{l}0.082 \\
0.478\end{array}$ \\
\hline N2 - mortgage loans to households & & & & & & $\begin{array}{l}0.068 \\
0.380\end{array}$ & $\begin{array}{l}0.149 \\
0.974\end{array}$ & $\begin{array}{l}0.059 \\
0.385\end{array}$ & $\begin{array}{l}0.125 \\
0.832\end{array}$ & $\begin{array}{l}0.090 \\
0.485\end{array}$ & & & & & & $\begin{array}{c}-0.144 \\
-1.824\end{array}$ & $\begin{array}{c}-0.175 \\
-2.304\end{array}$ & $\begin{array}{r}-0.404 \\
-0.826\end{array}$ & $\begin{array}{r}-0.197 \\
-1.733\end{array}$ & $\begin{array}{r}-0.241 \\
-0.844\end{array}$ \\
\hline N3 - consumer loans to households & & & & & & $\begin{array}{l}0.381 \\
1.907\end{array}$ & $\begin{array}{l}0.016 \\
0.096\end{array}$ & $\begin{array}{l}0.054 \\
0.316\end{array}$ & $\begin{array}{l}0.035 \\
0.210\end{array}$ & $\begin{array}{l}-0.064 \\
-0.308\end{array}$ & & & & & & $\begin{array}{l}-0.115 \\
-1.312\end{array}$ & $\begin{array}{l}-0.184 \\
-2.167\end{array}$ & $\begin{array}{r}-0.501 \\
-0.919\end{array}$ & $\begin{array}{l}-0.263 \\
-2.071\end{array}$ & $\begin{array}{l}-0.348 \\
-1.093\end{array}$ \\
\hline $\mathrm{N} 4$ - short-term loans to enterprises & & & & & & $\begin{array}{l}0.035 \\
0.199\end{array}$ & $\begin{array}{l}0.144 \\
0.958\end{array}$ & $\begin{array}{l}0.064 \\
0.425\end{array}$ & $\begin{array}{c}-0.039 \\
-0.266\end{array}$ & $\begin{array}{l}-0.128 \\
-0.698\end{array}$ & & & & & & $\begin{array}{l}0.005 \\
0.060\end{array}$ & $\begin{array}{c}-0.122 \\
-1.633\end{array}$ & $\begin{array}{r}-0.132 \\
-0.276\end{array}$ & $\begin{array}{l}0.036 \\
0.319\end{array}$ & $\begin{array}{r}-0.021 \\
-0.076\end{array}$ \\
\hline N5 - medium and long-term loans to enterprises & & & & & & $\begin{array}{l}0.005 \\
0.027\end{array}$ & $\begin{array}{r}-0.130 \\
-0.813\end{array}$ & $\begin{array}{c}-0.026 \\
-0.164\end{array}$ & $\begin{array}{c}-0.084 \\
-0.534\end{array}$ & $\begin{array}{r}-0.163 \\
-0.838\end{array}$ & & & & & & $\begin{array}{c}-0.058 \\
-0.706\end{array}$ & $\begin{array}{r}-0.239 \\
-3.008\end{array}$ & $\begin{array}{c}-0.112 \\
-0.219\end{array}$ & $\begin{array}{l}0.015 \\
0.129\end{array}$ & $\begin{array}{r}-0.085 \\
-0.286\end{array}$ \\
\hline N7 - current account deposits & & & & & & $\begin{array}{l}0.266 \\
1.288\end{array}$ & $\begin{array}{l}0.509 \\
2.890\end{array}$ & $\begin{array}{l}0.679 \\
3.842\end{array}$ & $\begin{array}{l}0.476 \\
2.753\end{array}$ & $\begin{array}{l}0.501 \\
2.334\end{array}$ & & & & & & $\begin{array}{l}-0.252 \\
-2.778\end{array}$ & $\begin{array}{l}-0.318 \\
-3.623\end{array}$ & $\begin{array}{l}-0.614 \\
-1.091\end{array}$ & $\begin{array}{l}-0.500 \\
-3.813\end{array}$ & $\begin{array}{l}-0.496 \\
-1.508\end{array}$ \\
\hline N8 - time deposits & & & & & & $\begin{array}{l}0.062 \\
0.351\end{array}$ & $\begin{array}{l}0.175 \\
1.162\end{array}$ & $\begin{array}{l}0.118 \\
0.778\end{array}$ & $\begin{array}{l}0.135 \\
0.915\end{array}$ & $\begin{array}{l}0.460 \\
2.505\end{array}$ & & & & & & $\begin{array}{l}0.004 \\
0.053\end{array}$ & $\begin{array}{c}-0.028 \\
-0.371\end{array}$ & $\begin{array}{r}-0.367 \\
-0.761\end{array}$ & $\begin{array}{c}-0.194 \\
-1.723\end{array}$ & $\begin{array}{c}-0.349 \\
-1.241\end{array}$ \\
\hline N9 - savings accounts & & & & & & $\begin{array}{l}0.387 \\
1.866\end{array}$ & $\begin{array}{l}0.449 \\
2.535\end{array}$ & $\begin{array}{l}0.355 \\
1.999\end{array}$ & $\begin{array}{l}0.297 \\
1.708\end{array}$ & $\begin{array}{l}0.584 \\
2.707\end{array}$ & & & & & & $\begin{array}{r}-0.303 \\
-3.316\end{array}$ & $\begin{array}{l}-0.390 \\
-4.429\end{array}$ & $\begin{array}{l}1.170 \\
2.065\end{array}$ & $\begin{array}{l}-0.389 \\
-2.952\end{array}$ & $\begin{array}{l}0.354 \\
1.071\end{array}$ \\
\hline Austria & & & & & & $\begin{array}{l}-0.531 \\
-2.228\end{array}$ & $\begin{array}{r}-0.353 \\
-1.734\end{array}$ & $\begin{array}{r}-0.753 \\
-3.689\end{array}$ & $\begin{array}{l}-0.525 \\
-2.629\end{array}$ & $\begin{array}{r}-0.368 \\
-1.484\end{array}$ & & & & & & $\begin{array}{l}-0.145 \\
-1.377\end{array}$ & $\begin{array}{c}-0.114 \\
-1.128\end{array}$ & $\begin{array}{l}0.318 \\
0.488\end{array}$ & $\begin{array}{c}-0.102 \\
-0.671\end{array}$ & $\begin{array}{l}0.145 \\
0.382\end{array}$ \\
\hline Belgium & & & & & & $\begin{array}{l}-0.501 \\
-2.331\end{array}$ & $\begin{array}{l}-0.238 \\
-1.300\end{array}$ & $\begin{array}{c}-0.526 \\
-2.861\end{array}$ & $\begin{array}{l}-0.279 \\
-1.549\end{array}$ & $\begin{array}{l}0.052 \\
0.233\end{array}$ & & & & & & $\begin{array}{c}-0.057 \\
-0.604\end{array}$ & $\begin{array}{c}-0.040 \\
-0.439\end{array}$ & $\begin{array}{l}0.005 \\
0.008\end{array}$ & $\begin{array}{l}-0.196 \\
-1.437\end{array}$ & $\begin{array}{r}-0.069 \\
-0.202\end{array}$ \\
\hline Finland & & & & & & $\begin{array}{r}-0.338 \\
-1.508\end{array}$ & $\begin{array}{r}-0.166 \\
-0.868\end{array}$ & $\begin{array}{l}-0.574 \\
-2.983\end{array}$ & $\begin{array}{r}-0.531 \\
-2.823\end{array}$ & $\begin{array}{l}-0.376 \\
-1.611\end{array}$ & & & & & & $\begin{array}{l}-0.032 \\
-0.329\end{array}$ & $\begin{array}{l}-0.048 \\
-0.505\end{array}$ & $\begin{array}{l}0.324 \\
0.530\end{array}$ & $\begin{array}{l}-0.157 \\
-1.099\end{array}$ & $\begin{array}{c}0.078 \\
0.218\end{array}$ \\
\hline Germany & & & & & & $\begin{array}{l}-0.431 \\
-2.062\end{array}$ & $\begin{array}{c}-0.174 \\
-0.976\end{array}$ & $\begin{array}{l}-0.363 \\
-2.025\end{array}$ & $\begin{array}{c}-0.294 \\
-1.675\end{array}$ & $\begin{array}{c}-0.033 \\
-0.153\end{array}$ & & & & & & $\begin{array}{l}-0.115 \\
-1.245\end{array}$ & $\begin{array}{r}-0.030 \\
-0.336\end{array}$ & $\begin{array}{l}1.142 \\
2.001\end{array}$ & $\begin{array}{r}-0.123 \\
-0.926\end{array}$ & $\begin{array}{l}0.580 \\
1.739\end{array}$ \\
\hline Ireland & & & & & & $\begin{array}{l}-0.460 \\
-2.106\end{array}$ & $\begin{array}{l}-0.375 \\
-2.013\end{array}$ & $\begin{array}{r}-0.674 \\
-3.598\end{array}$ & $\begin{array}{l}-0.556 \\
-3.038\end{array}$ & $\begin{array}{r}-0.386 \\
-1.697\end{array}$ & & & & & & $\begin{array}{l}0.096 \\
0.993\end{array}$ & $\begin{array}{l}0.093 \\
1.005\end{array}$ & $\begin{array}{l}-0.250 \\
-0.419\end{array}$ & $\begin{array}{r}-0.149 \\
-1.076\end{array}$ & $\begin{array}{r}-0.080 \\
-0.229\end{array}$ \\
\hline Italy & & & & & & $\begin{array}{c}-0.393 \\
-1.791\end{array}$ & $\begin{array}{l}-0.272 \\
-1.455\end{array}$ & $\begin{array}{l}-0.446 \\
-2.375\end{array}$ & $\begin{array}{l}-0.433 \\
-2.355\end{array}$ & $\begin{array}{c}0.020 \\
0.087\end{array}$ & & & & & & $\begin{array}{l}-0.177 \\
-1.836\end{array}$ & $\begin{array}{c}-0.137 \\
-1.471\end{array}$ & $\begin{array}{l}0.208 \\
0.348\end{array}$ & $\begin{array}{r}-0.225 \\
-1.617\end{array}$ & $\begin{array}{c}-0.032 \\
-0.091\end{array}$ \\
\hline Netherlands & & & & & & $\begin{array}{r}-0.227 \\
-0.957\end{array}$ & $\begin{array}{l}-0.317 \\
-1.568\end{array}$ & $\begin{array}{l}-0.572 \\
-2.817\end{array}$ & $\begin{array}{l}-0.437 \\
-2.200\end{array}$ & $\begin{array}{r}-0.343 \\
-1.391\end{array}$ & & & & & & $\begin{array}{l}-0.130 \\
-1.243\end{array}$ & $\begin{array}{c}-0.184 \\
-1.823\end{array}$ & $\begin{array}{l}0.234 \\
0.362\end{array}$ & $\begin{array}{c}-0.207 \\
-1.374\end{array}$ & $\begin{array}{l}0.128 \\
0.338\end{array}$ \\
\hline Portugal & & & & & & $\begin{array}{r}-0.263 \\
-1.158\end{array}$ & $\begin{array}{r}-0.354 \\
-1.828\end{array}$ & $\begin{array}{r}-0.683 \\
-3.514\end{array}$ & $\begin{array}{l}-0.633 \\
-3.331\end{array}$ & $\begin{array}{c}-0.444 \\
-1.880\end{array}$ & & & & & & $\begin{array}{l}-0.244 \\
-2.441\end{array}$ & $\begin{array}{r}-0.167 \\
-1.733\end{array}$ & $\begin{array}{l}0.262 \\
0.423\end{array}$ & $\begin{array}{c}-0.141 \\
-0.980\end{array}$ & $\begin{array}{c}0.189 \\
0.523\end{array}$ \\
\hline Spain & & & & & & $\begin{array}{c}-0.166 \\
-0.769\end{array}$ & $\begin{array}{l}0.021 \\
0.117\end{array}$ & $\begin{array}{l}-0.282 \\
-1.525\end{array}$ & $\begin{array}{c}-0.318 \\
-1.758\end{array}$ & $\begin{array}{c}-0.091 \\
-0.407\end{array}$ & & & & & & $\begin{array}{r}-0.003 \\
-0.033\end{array}$ & $\begin{array}{c}-0.030 \\
-0.328\end{array}$ & $\begin{array}{l}0.401 \\
0.681\end{array}$ & $\begin{array}{c}-0.054 \\
-0.397\end{array}$ & $\begin{array}{l}0.162 \\
0.472\end{array}$ \\
\hline $\begin{array}{l}\text { adjusted } R^{2} \\
\text { number of observations }\end{array}$ & $\begin{array}{r}2.8 \% \\
130\end{array}$ & $\begin{array}{r}6.8 \% \\
130\end{array}$ & $\begin{array}{r}4.8 \% \\
130\end{array}$ & $\begin{array}{r}7.7 \% \\
130\end{array}$ & $\begin{array}{r}11.5 \% \\
130\end{array}$ & $\begin{array}{r}6.0 \% \\
130\end{array}$ & $\begin{array}{r}15.7 \% \\
130\end{array}$ & $\begin{array}{r}23.8 \% \\
130\end{array}$ & $\begin{array}{r}18.6 \% \\
130\end{array}$ & $\begin{array}{r}26.3 \% \\
130\end{array}$ & $\begin{array}{r}4.5 \% \\
130\end{array}$ & $\begin{array}{r}3.3 \% \\
130\end{array}$ & $\begin{array}{r}-1.5 \% \\
130\end{array}$ & $\begin{array}{r}9.6 \% \\
130\end{array}$ & $\begin{array}{r}-1.1 \% \\
130\end{array}$ & $\begin{array}{r}25.2 \% \\
130\end{array}$ & $\begin{array}{r}26.1 \% \\
130\end{array}$ & $\begin{array}{r}4.8 \% \\
130\end{array}$ & $\begin{array}{r}24.0 \% \\
130\end{array}$ & $\begin{array}{r}1.1 \% \\
130\end{array}$ \\
\hline
\end{tabular}

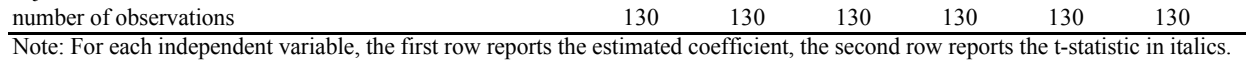


Table A1: Unit root tests

\begin{tabular}{|c|c|c|c|c|c|c|c|c|c|}
\hline \multirow[b]{2}{*}{ country } & \multirow[b]{2}{*}{ bankrate } & \multirow[b]{2}{*}{$\mathrm{t}($ level $)$} & \multicolumn{3}{|c|}{$\begin{array}{l}\mathrm{I}(?) \\
\end{array}$} & \multirow[b]{2}{*}{ F(level) } & \multirow[b]{2}{*}{$F($ diff $)$} & \multicolumn{2}{|c|}{$\mathrm{I}(?)$} \\
\hline & & & $t(\operatorname{diff})$ & $10 \%$ & $5 \%$ & & & $10 \%$ & $5 \%$ \\
\hline \multirow[t]{5}{*}{ Austria } & 2 & -0.46 & -2.68 & 1 & 2 & 2.57 & 3.89 & 2 & 2 \\
\hline & 3 & -0.64 & -3.33 & 1 & 1 & 1.80 & 5.95 & 1 & 2 \\
\hline & 4 & -0.88 & -2.85 & 1 & 2 & 1.44 & 4.16 & 2 & 2 \\
\hline & 7 & -2.33 & -4.44 & 1 & 1 & 2.75 & 9.95 & 1 & 1 \\
\hline & 8 & -0.71 & -2.96 & 1 & 1 & 1.02 & 4.38 & 2 & 2 \\
\hline \multirow[t]{7}{*}{ Belgium } & 2 & -1.62 & -4.93 & 1 & 1 & 7.38 & 12.15 & 0 & 0 \\
\hline & 3 & -1.56 & -4.51 & 1 & 1 & 2.83 & 10.19 & 1 & 1 \\
\hline & 4.1 & -0.81 & -4.07 & 1 & 1 & 2.74 & 8.36 & 1 & 1 \\
\hline & 4.2 & -0.62 & -3.98 & 1 & 1 & 1.16 & 7.93 & 1 & 1 \\
\hline & 5 & -2.20 & -3.98 & 1 & 1 & 3.84 & 7.90 & 1 & 1 \\
\hline & 8 & -0.62 & -3.84 & 1 & 1 & 2.01 & 7.53 & 1 & 1 \\
\hline & 9 & -0.15 & -2.36 & 2 & 2 & 1.38 & 3.69 & 2 & 2 \\
\hline Finland & 2 & -1.03 & -3.44 & 1 & 1 & 2.38 & 5.97 & 1 & 2 \\
\hline & 3 & -0.85 & -3.64 & 1 & 1 & 2.53 & 6.67 & 1 & 1 \\
\hline & 5 & -0.64 & -5.09 & 1 & 1 & 1.60 & 13.01 & 1 & 1 \\
\hline & 6 & -0.62 & -4.14 & 1 & 1 & 1.86 & 8.65 & 1 & 1 \\
\hline & 7 & -1.05 & -4.28 & 1 & 1 & 0.93 & 9.15 & 1 & 1 \\
\hline & 8 & -1.91 & -4.48 & 1 & 1 & 1.89 & 10.02 & 1 & 1 \\
\hline & 10 & -1.01 & -2.90 & 1 & 1 & 1.47 & 4.21 & 2 & 2 \\
\hline France & 4 & -0.94 & -5.17 & 1 & 1 & 1.54 & 13.35 & 1 & 1 \\
\hline & 5 & -0.64 & -5.16 & 1 & 1 & 1.33 & 13.31 & 1 & 1 \\
\hline & 8 & -1.01 & -3.68 & 1 & 1 & 1.86 & 6.81 & 1 & 1 \\
\hline & 9 & -2.51 & -4.78 & 1 & 1 & 3.38 & 11.43 & 1 & 1 \\
\hline Germany & 2 & -1.85 & -4.23 & 1 & 1 & 4.80 & 8.97 & 1 & 1 \\
\hline & 3 & -1.32 & -4.22 & 1 & 1 & 1.08 & 8.95 & 1 & 1 \\
\hline & 4 & -0.96 & -2.56 & 2 & 2 & 1.48 & 3.47 & 2 & 2 \\
\hline & 5 & -1.82 & -4.50 & 1 & 1 & 5.06 & 10.22 & 1 & 1 \\
\hline & 8.1 & -1.16 & -3.10 & 1 & 1 & 1.61 & 4.80 & 2 & 2 \\
\hline & 8.2 & -1.42 & -3.30 & 1 & 1 & 1.90 & 5.45 & 2 & 2 \\
\hline & 9.1 & -1.24 & -2.66 & 1 & 2 & 1.47 & 3.62 & 2 & 2 \\
\hline & 9.2 & -1.18 & -3.04 & 1 & 1 & 2.43 & 4.65 & 2 & 2 \\
\hline Ireland & 1 & -1.13 & -3.76 & 1 & 1 & 1.47 & 7.06 & 1 & 1 \\
\hline & 2 & -1.52 & -4.49 & 1 & 1 & 1.23 & 10.08 & 1 & 1 \\
\hline & 4 & -1.05 & -3.66 & 1 & 1 & 1.26 & 6.69 & 1 & 1 \\
\hline & 5 & -0.89 & -3.61 & 1 & 1 & 1.68 & 6.53 & 1 & 1 \\
\hline & 6 & -0.70 & -3.44 & 1 & 1 & 1.60 & 5.92 & 1 & 2 \\
\hline & 9.1 & -1.35 & -4.05 & 1 & 1 & 1.54 & 8.19 & 1 & 1 \\
\hline & 9.2 & -1.26 & -4.09 & 1 & 1 & 1.09 & 8.38 & 1 & 1 \\
\hline Italy & 2 & -0.70 & -4.82 & 1 & 1 & 0.84 & 11.64 & 1 & 1 \\
\hline & 4.1 & -1.61 & -3.00 & 1 & 1 & 1.83 & 4.98 & 2 & 2 \\
\hline & 4.2 & -1.78 & -2.27 & 2 & 2 & 2.43 & 2.62 & 2 & 2 \\
\hline & 5 & -0.55 & -5.47 & 1 & 1 & 1.85 & 15.15 & 1 & 1 \\
\hline & 7 & -1.25 & -2.59 & 1 & 2 & 1.97 & 3.36 & 2 & 2 \\
\hline & 8 & -0.93 & -3.33 & 1 & 1 & 2.16 & 5.55 & 1 & 2 \\
\hline & 10 & -1.49 & -2.51 & 2 & 2 & 1.78 & 3.17 & 2 & 2 \\
\hline Netherlands & 2 & -1.80 & -3.97 & 1 & 1 & 3.89 & 7.91 & 1 & 1 \\
\hline & 4 & -0.68 & -4.05 & 1 & 1 & 1.43 & 8.21 & 1 & 1 \\
\hline & 7 & -1.02 & -5.85 & 1 & 1 & 2.30 & 17.14 & 1 & 1 \\
\hline & 8.1 & -1.41 & -3.44 & 1 & 1 & 2.41 & 5.92 & 1 & 2 \\
\hline & 8.2 & -1.75 & -3.75 & 1 & 1 & 3.30 & 7.02 & 1 & 1 \\
\hline Portugal & 2 & -1.24 & -2.88 & 1 & 1 & 1.25 & 4.33 & 2 & 2 \\
\hline & 3 & -2.18 & -6.82 & 1 & 1 & 2.69 & 23.30 & 1 & 1 \\
\hline & 4.1 & -1.09 & -3.54 & 1 & 1 & 0.76 & 6.82 & 1 & 1 \\
\hline & 4.2 & -1.14 & -5.15 & 1 & 1 & 0.78 & 13.54 & 1 & 1 \\
\hline & 8.1 & -1.20 & -3.40 & 1 & 1 & 1.06 & 5.84 & 1 & 2 \\
\hline & 8.2 & -0.60 & -3.45 & 1 & 1 & 1.03 & 6.22 & 1 & 2 \\
\hline Spain & 2 & -1.68 & -2.75 & 1 & 2 & 2.48 & 3.85 & 2 & 2 \\
\hline & 3 & -1.53 & -6.88 & 1 & 1 & 1.34 & 23.70 & 1 & 1 \\
\hline & 4 & -0.69 & -5.06 & 1 & 1 & 1.67 & 12.83 & 1 & 1 \\
\hline & 5 & -0.73 & -5.02 & 1 & 1 & 1.18 & 12.62 & 1 & 1 \\
\hline & 6 & -0.93 & -3.18 & 1 & 1 & 1.23 & 5.11 & 2 & 2 \\
\hline & 7 & -1.01 & -2.47 & 2 & 2 & 1.01 & 3.21 & 2 & 2 \\
\hline & 8 & -0.86 & -3.75 & 1 & 1 & 1.83 & 7.03 & 1 & 1 \\
\hline & 10.1 & -0.86 & -3.13 & 1 & 1 & 1.20 & 4.94 & 2 & 2 \\
\hline & 10.2 & -1.16 & -2.69 & 1 & 2 & 1.82 & 3.63 & 2 & 2 \\
\hline MP rate & & -0.81 & -3.99 & 1 & 1 & 1.42 & 7.97 & 1 & 1 \\
\hline $\exp$ MP rate & & -0.69 & -4.13 & 1 & 1 & 1.81 & 8.57 & 1 & 1 \\
\hline unexp MP rate & & -5.99 & -10.03 & 0 & 0 & 18 & 50.52 & 0 & 0 \\
\hline
\end{tabular}


Table A2: The longrun relationship between bank rate and money market rate and symmetric cointegration tests

\begin{tabular}{|c|c|c|c|c|c|c|c|c|c|}
\hline \multicolumn{10}{|c|}{ Panel A: Monetary policy rates } \\
\hline regression & & intercept & t-stat & slope & t-stat & DW & $\mathrm{DF}$ & $\mathrm{ADF}$ & coint? \\
\hline \multicolumn{2}{|c|}{$\mathrm{MP}=\theta_{0}+\theta \mathrm{MPE}$} & -0.02 & -0.26 & 1.00 & 51.63 & 2.46 & -9.07 & & yes \\
\hline \multicolumn{10}{|c|}{ Panel B: Bankrates } \\
\hline country & bankrate & intercept & t-stat & slope & t-stat & DW & DF & $\mathrm{ADF}$ & coint? \\
\hline \multirow[t]{5}{*}{ Austria } & 2 & 3.42 & 49.45 & 0.61 & 32.49 & 0.86 & -3.84 & & yes \\
\hline & 3 & 4.73 & 60.13 & 0.61 & 28.52 & 0.59 & -3.22 & & yes \\
\hline & 4 & 3.77 & 45.36 & 0.63 & 27.66 & 0.72 & -3.61 & & yes \\
\hline & 7 & 0.21 & 7.85 & 0.02 & 3.09 & 0.14 & -2.59 & & no \\
\hline & 8 & 0.95 & 11.62 & 0.44 & 19.48 & 0.49 & -2.86 & & yes \\
\hline \multirow[t]{7}{*}{ Belgium } & 2 & 3.37 & 14.79 & 0.72 & 11.67 & 0.26 & -2.46 & -3.23 & yes \\
\hline & 3 & 5.54 & 28.52 & 0.45 & 8.57 & 0.23 & -2.37 & & no \\
\hline & 4.1 & 1.16 & 5.91 & 0.92 & 17.37 & 0.40 & -2.23 & -2.57 & yes \\
\hline & 4.2 & 4.62 & 23.61 & 0.85 & 16.01 & 0.23 & -1.74 & -0.69 & no \\
\hline & 5 & 5.06 & 14.04 & 0.34 & 3.50 & 0.13 & -2.39 & -3.85 & yes \\
\hline & 8 & -0.09 & -0.69 & 0.83 & 23.95 & 0.54 & -2.43 & -1.61 & yes \\
\hline & 9 & 2.52 & 77.89 & 0.02 & 2.67 & 0.45 & -0.42 & -1.98 & yes \\
\hline \multirow[t]{7}{*}{ Finland } & 2 & 1.59 & 7.64 & 0.94 & 16.52 & 0.19 & -1.14 & -0.44 & no \\
\hline & 3 & 2.75 & 13.19 & 0.94 & 16.58 & 0.28 & -1.56 & -0.70 & no \\
\hline & 5 & 1.16 & 8.52 & 0.93 & 25.23 & 1.58 & -5.75 & & yes \\
\hline & 6 & 1.27 & 11.07 & 0.90 & 28.92 & 1.11 & -4.31 & & yes \\
\hline & 7 & 0.07 & 1.35 & 0.20 & 13.71 & 0.47 & -3.28 & & yes \\
\hline & 8 & 3.64 & 14.01 & -0.10 & -1.37 & 0.17 & -0.97 & & no \\
\hline & 10 & 0.24 & 3.20 & 0.36 & 17.96 & 0.31 & -2.09 & & no \\
\hline \multirow[t]{4}{*}{ France } & 4 & 2.09 & 16.72 & 0.79 & 23.08 & 1.54 & -5.68 & & yes \\
\hline & 5 & 2.46 & 13.37 & 0.72 & 14.29 & 0.49 & -2.72 & -2.46 & yes \\
\hline & 8 & 0.10 & 0.97 & 0.98 & 35.87 & 0.77 & -3.37 & -2.73 & yes \\
\hline & 9 & 2.75 & 15.91 & 0.05 & 1.15 & 0.23 & -1.81 & & no \\
\hline \multirow[t]{8}{*}{ Germany } & 2 & 3.55 & 11.62 & 0.56 & 6.78 & 0.15 & -1.54 & -2.66 & no \\
\hline & 3 & 9.82 & 69.92 & 0.19 & 5.07 & 0.08 & -0.85 & -0.55 & no \\
\hline & 4 & 6.52 & 26.62 & 0.50 & 7.47 & 0.05 & -0.88 & & no \\
\hline & 5 & 4.51 & 19.94 & 0.50 & 8.07 & 0.17 & -2.19 & -3.19 & yes \\
\hline & 8.1 & -0.06 & -0.96 & 0.73 & 41.64 & 0.48 & -2.80 & -1.65 & yes \\
\hline & 8.2 & 0.09 & 1.28 & 0.82 & 43.62 & 0.78 & -3.44 & -1.26 & yes \\
\hline & 9.1 & 1.01 & 9.24 & 0.27 & 9.17 & 0.07 & -1.22 & & no \\
\hline & 9.2 & 0.41 & 2.90 & 0.76 & 19.57 & 0.31 & -1.65 & & no \\
\hline \multirow[t]{7}{*}{ Ireland } & 1 & 8.40 & 62.58 & 0.78 & 21.34 & 0.29 & -2.02 & -1.41 & no \\
\hline & 2 & 2.70 & 9.48 & 0.63 & 8.19 & 0.18 & -2.23 & -3.02 & no \\
\hline & 4 & 6.47 & 57.90 & 0.70 & 22.98 & 0.35 & -2.04 & -1.16 & no \\
\hline & 5 & 5.73 & 50.18 & 0.66 & 21.33 & 0.32 & -2.31 & -1.27 & no \\
\hline & 6 & 0.51 & 12.35 & 1.01 & 90.00 & 1.41 & -5.28 & & yes \\
\hline & 9.1 & -0.53 & -13.19 & 0.22 & 19.79 & 0.40 & -2.31 & & yes \\
\hline & 9.2 & -0.63 & -8.11 & 0.28 & 13.41 & 0.20 & -1.98 & -1.64 & no \\
\hline Italy & 2 & 3.86 & 29.82 & 0.60 & 17.13 & 0.84 & -4.04 & -3.56 & yes \\
\hline & 4.1 & 3.74 & 33.06 & 0.62 & 20.23 & 0.39 & -3.99 & & yes \\
\hline & 4.2 & 0.70 & 5.59 & 0.81 & 23.73 & 0.42 & -2.49 & & yes \\
\hline & 5 & 2.35 & 23.52 & 0.72 & 26.51 & 1.58 & -5.83 & & yes \\
\hline & 7 & -0.03 & -0.49 & 0.42 & 26.27 & 0.56 & -3.25 & & yes \\
\hline & 8 & 0.74 & 7.49 & 0.64 & 23.91 & 0.40 & -1.50 & & yes \\
\hline & 10 & 0.40 & 3.66 & 0.35 & 11.62 & 0.13 & -2.86 & & no \\
\hline Netherlands & 2 & 3.75 & 14.39 & 0.56 & 7.86 & 0.16 & -1.24 & -1.93 & no \\
\hline & 4 & 0.68 & 9.90 & 0.98 & 52.19 & 2.23 & -8.01 & -2.47 & yes \\
\hline & 7 & 0.27 & 6.78 & 0.04 & 3.46 & 0.09 & -0.41 & & no \\
\hline & 8.1 & 1.47 & 9.22 & 0.56 & 12.82 & 0.31 & -2.23 & & no \\
\hline & 8.2 & 2.22 & 11.72 & 0.46 & 8.87 & 0.19 & -2.01 & -2.59 & no \\
\hline Portugal & 2 & 2.48 & 17.89 & 0.83 & 21.87 & 0.55 & -3.56 & & yes \\
\hline & 3 & 8.15 & 22.93 & 0.46 & 4.71 & 1.21 & -4.74 & -2.71 & yes \\
\hline & 4.1 & 6.10 & 23.44 & 0.38 & 5.47 & 0.27 & -3.63 & & yes \\
\hline & 4.2 & 3.21 & 15.59 & 0.63 & 11.47 & 0.69 & -3.85 & & yes \\
\hline & 8.1 & 0.62 & 3.58 & 0.74 & 16.06 & 0.32 & -1.93 & & no \\
\hline & 8.2 & 1.07 & 7.62 & 0.51 & 13.50 & 0.56 & -2.76 & -1.39 & yes \\
\hline Spain & 2 & 2.19 & 14.78 & 0.84 & 20.76 & 0.40 & -2.07 & -1.24 & yes \\
\hline & 3 & 5.70 & 32.43 & 0.63 & 13.21 & 1.40 & -5.72 & & yes \\
\hline & 4 & 1.58 & 13.26 & 0.85 & 26.28 & 1.67 & -6.06 & & yes \\
\hline & 5 & 3.45 & 33.60 & 0.72 & 25.75 & 1.60 & -5.97 & & yes \\
\hline & 6 & 2.36 & 16.58 & 0.81 & 20.84 & 0.43 & -2.51 & -2.16 & yes \\
\hline & 7 & 0.52 & 6.39 & 0.40 & 18.16 & 0.23 & -1.86 & & no \\
\hline & 8 & 0.07 & 0.58 & 0.76 & 23.14 & 0.80 & -3.60 & & yes \\
\hline & 10.1 & -0.15 & -2.67 & 1.00 & 65.74 & 1.63 & -6.19 & -1.51 & yes \\
\hline & 10.2 & 0.33 & 4.10 & 0.55 & 25.24 & 0.34 & -2.18 & -1.57 & no \\
\hline
\end{tabular}


Table A3: Optimal pass-through model selection

\begin{tabular}{|c|c|c|c|c|c|c|c|c|c|c|c|c|c|c|c|}
\hline \multirow[b]{2}{*}{ country } & \multirow[b]{2}{*}{ bankrate } & \multicolumn{5}{|c|}{ AIC } & \multirow[b]{2}{*}{$\min \mathrm{AIC}$} & \multirow{2}{*}{$\begin{array}{r}\text { optimal } \\
\text { TAR model }\end{array}$} & \multicolumn{5}{|c|}{ asymmetric cointegration } & \multirow{2}{*}{$\begin{array}{r}\text { symmetric } \\
\text { cointegration? }\end{array}$} & \multirow{2}{*}{$\begin{array}{r}\text { pass-through } \\
\text { model }\end{array}$} \\
\hline & & TAR $^{0}$ & TAR* & BTAR* & MTAR $^{0}$ & MTAR* $^{*}$ & & & coint & $\mathrm{H}_{0}: \rho_{1}=\rho_{2}$ & $\mathrm{H}_{0}: \rho_{1}=\rho_{3}$ & $\mathrm{H}_{0}: \rho_{2}=\rho_{3}$ & coint? & & \\
\hline Austria & 2 & -45.26 & -45.63 & -49.66 & -45.83 & -51.95 & -51.95 & MTAR* & 9.06 & 6.37 & & & yes, asym & yes & MTAR* \\
\hline & 3 & -48.98 & -53.98 & -47.43 & -48.81 & -53.86 & -53.98 & TAR* & 9.03 & 6.54 & & & yes, asym & yes & TAR* \\
\hline & 4 & -34.30 & -34.83 & -33.94 & -33.77 & -35.01 & -35.01 & MTAR* & 6.71 & 1.59 & & & yes, sym & yes & SYM \\
\hline & 7 & -238.55 & -240.91 & -240.36 & -227.96 & -231.35 & -240.91 & TAR* & 9.04 & 10.20 & & & yes, asym & no & TAR* \\
\hline & 8 & -51.31 & -56.37 & -57.11 & -53.93 & -55.21 & -57.11 & BTAR* & 5.77 & 2.65 & 2.06 & 8.04 & no & yes & SYM \\
\hline Belgium & 2 & 14.26 & 11.94 & 7.98 & 15.08 & 10.86 & 7.98 & BTAR* & 7.65 & 7.89 & 0.89 & 7.34 & yes, asym & yes & BTAR* \\
\hline & 3 & 0.61 & -0.62 & -5.65 & -0.34 & -2.82 & -5.65 & BTAR* & 5.57 & 8.27 & 0.41 & 8.35 & no & no & STD \\
\hline & 4.1 & 30.80 & 29.44 & 29.82 & 30.65 & 22.09 & 22.09 & MTAR* & 6.91 & 8.56 & & & yes, asym & yes & MTAR* \\
\hline & 4.2 & -6.05 & -12.39 & -10.28 & -13.43 & -18.74 & -18.74 & MTAR* & 7.84 & 15.06 & & & yes, asym & no & MTAR* \\
\hline & 5 & 20.93 & 19.99 & 18.44 & 21.10 & 17.23 & 17.23 & MTAR* & 9.50 & 3.62 & & & yes, asym & yes & MTAR* \\
\hline & 8 & -4.69 & -5.74 & -10.42 & -6.22 & -14.23 & -14.23 & MTAR* & 5.44 & 9.97 & & & no & yes & SYM \\
\hline & 9 & -146.36 & -147.39 & -166.95 & -145.85 & -146.28 & -166.95 & BTAR* & 10.96 & 26.22 & 0.03 & 25.64 & yes, asym & yes & BTAR* \\
\hline Finland & 2 & -0.82 & -1.94 & -7.86 & -0.01 & -7.96 & -7.96 & MTAR* & 4.63 & 9.03 & & & no & no & STD \\
\hline & 3 & 15.26 & 14.65 & 14.16 & 11.71 & 8.19 & 8.19 & MTAR* & 5.39 & 10.21 & & & no & no & STD \\
\hline & 5 & 40.21 & 38.04 & 31.95 & 40.55 & 37.80 & 31.95 & BTAR* & 6.26 & 7.04 & 0.00 & 9.32 & (yes, asym) & yes & BTAR* \\
\hline & 6 & 13.18 & 9.91 & 8.21 & 12.96 & 5.86 & 5.86 & MTAR* & 5.14 & 7.27 & & & no & yes & SYM \\
\hline & 7 & -107.35 & -110.60 & -112.99 & -101.09 & -106.19 & -112.99 & BTAR* & 11.77 & 8.39 & 7.07 & 6.53 & yes, asym & yes & BTAR* \\
\hline & 8 & 18.32 & 17.42 & 18.12 & 13.54 & -47.75 & -47.75 & MTAR* & 69.10 & 133.12 & & & yes, asym & no & MTAR* \\
\hline & 10 & -82.04 & -83.50 & -82.41 & -80.94 & -87.99 & -87.99 & MTAR* & 6.31 & 7.63 & & & (yes, asym) & no & MTAR* \\
\hline France & 4 & 32.09 & 30.09 & 29.44 & 31.98 & 30.00 & 29.44 & BTAR* & 7.80 & 4.52 & 1.26 & 2.39 & yes, asym & yes & BTAR* \\
\hline & 5 & 20.05 & 18.57 & 18.20 & 21.47 & 15.13 & 15.13 & MTAR* & 3.96 & 5.93 & & & no & yes & SYM \\
\hline & 8 & -11.21 & -13.09 & -20.88 & -14.62 & -25.06 & -25.06 & MTAR* & 9.24 & 14.77 & & & yes, asym & yes & MTAR* \\
\hline & 9 & -9.21 & -12.25 & -10.82 & -9.69 & -11.58 & -12.25 & TAR* & 3.25 & 3.09 & & & no & no & STD \\
\hline Germany & 2 & 20.60 & 17.70 & 13.83 & 20.66 & 16.71 & 13.83 & BTAR* & 5.13 & 6.37 & 0.42 & 5.47 & no & no & STD \\
\hline & 3 & -83.63 & -88.14 & -90.13 & -83.71 & -86.18 & -90.13 & BTAR* & 3.18 & 7.87 & 1.13 & 3.90 & no & no & STD \\
\hline & 4 & -46.40 & -49.48 & -47.88 & -43.92 & -51.84 & -51.84 & MTAR* & 4.75 & 8.53 & & & no & no & STD \\
\hline & 5 & -5.56 & -7.82 & -11.00 & -5.68 & -30.39 & -30.39 & MTAR* & 21.77 & 29.03 & & & yes, asym & yes & MTAR* \\
\hline & 8.1 & -82.43 & -83.80 & -85.92 & -80.99 & -91.98 & -91.98 & MTAR* & 7.81 & 11.33 & & & yes, asym & yes & MTAR* \\
\hline & 8.2 & -53.89 & -53.95 & -57.41 & -52.57 & -59.22 & -59.22 & MTAR* & 4.38 & 6.51 & & & no & yes & SYM \\
\hline & 9.1 & -133.49 & -136.21 & -135.56 & -123.24 & -131.48 & -136.21 & TAR* & 11.16 & 22.31 & & & yes, asym & no & TAR* \\
\hline & 9.2 & -13.15 & -15.48 & -18.03 & -13.50 & -28.31 & -28.31 & MTAR* & 10.91 & 18.36 & & & yes, asym & no & MTAR* \\
\hline Ireland & 1 & -34.51 & -54.26 & -42.57 & -42.21 & -44.95 & -54.26 & TAR* & 13.70 & 27.01 & & & yes, asym & no & TAR* \\
\hline & 2 & 24.61 & 22.01 & 17.33 & 23.23 & 16.77 & 16.77 & MTAR* & 9.98 & 9.15 & & & yes, asym & no & MTAR* \\
\hline & 4 & -44.14 & -60.34 & -45.21 & -49.78 & -53.61 & -60.34 & TAR* & 10.89 & 21.57 & & & yes, asym & no & TAR* \\
\hline & 5 & -56.33 & -68.74 & -67.15 & -64.02 & -65.79 & -68.74 & TAR* & 9.33 & 18.65 & & & yes, asym & no & TAR* \\
\hline & 6 & -82.55 & -84.02 & -83.90 & -82.25 & -82.94 & -84.02 & TAR* & 14.81 & 1.47 & & & yes, sym & yes & SYM \\
\hline & 9.1 & -133.32 & -134.07 & -149.02 & -131.69 & -135.64 & -149.02 & BTAR* & 9.03 & 19.83 & 0.04 & 19.88 & yes, asym & yes & BTAR* \\
\hline & 9.2 & -99.03 & -100.34 & -104.95 & -99.36 & -101.63 & -104.95 & BTAR* & 3.75 & 7.90 & 0.29 & 7.97 & yes, asym & no & BTAR* \\
\hline Italy & 2 & 15.33 & 14.46 & 12.21 & 15.12 & 12.99 & 12.21 & BTAR* & 2.75 & 4.63 & 0.07 & 4.62 & no & yes & SYM \\
\hline & 4.1 & -36.71 & -37.01 & -40.05 & -36.63 & -42.76 & -42.76 & MTAR* & 8.19 & 6.44 & & & yes, asym & yes & MTAR* \\
\hline & 4.2 & -13.34 & -13.71 & -16.02 & -14.55 & -25.07 & -25.07 & MTAR* & 9.56 & 12.13 & & & yes, asym & yes & MTAR* \\
\hline & 5 & 5.90 & 4.21 & 2.84 & 5.85 & 0.73 & 0.73 & MTAR* & 7.16 & 4.96 & & & yes, asym & yes & MTAR* \\
\hline & 7 & -82.61 & -85.87 & -87.41 & -83.53 & -92.74 & -92.74 & MTAR* & 7.88 & 10.70 & & & yes, asym & yes & MTAR* \\
\hline & 8 & -42.70 & -45.97 & -54.11 & -38.55 & -43.62 & -54.11 & BTAR* & 8.17 & 12.87 & 7.68 & 14.49 & yes, asym & yes & BTAR* \\
\hline & 10 & -92.28 & -92.69 & -99.57 & -92.46 & -95.69 & -99.57 & BTAR* & 7.27 & 8.97 & 7.72 & 9.24 & yes, asym & no & BTAR* \\
\hline Netherlands & 2 & 13.16 & 12.16 & 11.75 & 12.98 & -4.50 & -4.50 & MTAR* & 13.70 & 19.25 & & & yes, asym & no & MTAR* \\
\hline & 4 & -25.33 & -30.47 & -29.65 & -25.01 & -29.74 & -30.47 & TAR* & 38.13 & 5.92 & & & yes, asym & yes & TAR* \\
\hline & 7 & -208.53 & -208.90 & -222.25 & -205.31 & -205.79 & -222.25 & BTAR* & 6.07 & 17.29 & 0.68 & 17.33 & (yes, asym) & no & BTAR* \\
\hline & 8.1 & -2.54 & -3.00 & -10.97 & -2.96 & -5.69 & -10.97 & BTAR* & 5.58 & 10.80 & 0.03 & 10.89 & no & no & STD \\
\hline & 8.2 & -10.54 & -11.51 & -11.63 & -10.51 & -13.29 & -13.29 & MTAR* & 4.31 & 2.69 & & & no & no & STD \\
\hline Portugal & 2 & 1.25 & -1.16 & -10.81 & 0.93 & -4.75 & -10.81 & BTAR* & 7.76 & 14.26 & 0.42 & 14.30 & yes, asym & yes & BTAR* \\
\hline & 3 & 123.88 & 122.75 & 119.96 & 123.39 & 122.23 & 119.96 & BTAR* & 3.21 & 5.40 & 0.10 & 5.38 & no & yes & SYM \\
\hline & 4.1 & 10.15 & 7.24 & 5.67 & 10.37 & 10.02 & 5.67 & BTAR* & 5.57 & 7.17 & 3.83 & 5.95 & no & yes & SYM \\
\hline & 4.2 & 30.39 & 29.68 & 29.53 & 30.03 & 29.14 & 29.14 & MTAR* & 6.41 & 1.93 & & & yes, asym & yes & MTAR* \\
\hline & 8.1 & -7.52 & -9.21 & -9.18 & -7.52 & -12.92 & -12.92 & MTAR* & 3.70 & 5.36 & & & no & no & STD \\
\hline & 8.2 & -16.10 & -16.80 & -19.22 & -15.52 & -18.30 & -19.22 & BTAR* & 2.54 & 4.41 & 0.75 & 5.03 & no & yes & SYM \\
\hline Spain & 2 & -7.62 & -12.34 & -11.08 & -1.04 & -10.98 & -12.34 & TAR* & 6.91 & 13.06 & & & yes, asym & yes & TAR* \\
\hline & 3 & 60.53 & 60.16 & 60.41 & 60.53 & 58.50 & 58.50 & MTAR* & 9.78 & 1.86 & & & (yes, asym) & yes & MTAR* \\
\hline & 4 & 11.07 & 10.06 & 6.64 & 11.44 & 10.59 & 6.64 & BTAR* & 4.86 & 4.89 & 0.66 & 6.20 & no & yes & SYM \\
\hline & 5 & 12.35 & 11.30 & 9.18 & 12.30 & 3.46 & 3.46 & MTAR* & 12.31 & 9.04 & & & yes, asym & yes & MTAR* \\
\hline & 6 & -1.40 & -4.38 & -8.45 & -0.69 & -2.41 & -8.45 & BTAR* & 3.79 & 5.53 & 0.26 & 9.88 & no & yes & SYM \\
\hline & 7 & -86.66 & -90.24 & -89.73 & -86.49 & -88.86 & -90.24 & TAR* & 3.91 & 4.14 & & & no & no & STD \\
\hline & 8 & 9.09 & 6.93 & 4.27 & 5.90 & 2.47 & 2.47 & MTAR* & 7.15 & 7.90 & & & yes, asym & yes & MTAR* \\
\hline & 10.1 & -51.74 & -52.86 & -51.20 & -54.09 & -54.44 & -54.44 & MTAR* & 22.82 & 5.99 & & & yes, asym & yes & MTAR* \\
\hline & 10.2 & -74.05 & -76.19 & -75.69 & -73.89 & -82.03 & -82.03 & MTAR* & 5.57 & 8.30 & & & no & no & STD \\
\hline
\end{tabular}


Table A4: Pass-through of $+1 \%$ shock in expected or unexpected monetary policy rate rate

\begin{tabular}{|c|c|c|c|c|c|c|c|c|c|c|c|c|c|}
\hline \multirow[b]{2}{*}{ country } & \multirow[b]{2}{*}{ bankrate } & \multicolumn{6}{|c|}{ multiplier associated with MPE shock } & \multicolumn{6}{|c|}{ multiplier associated with MPU shock } \\
\hline & & impact & $1 \mathrm{mth}$ & $3 \mathrm{mths}$ & $6 \mathrm{mths}$ & 12 month & longrun & impact & $1 \mathrm{mth}$ & $3 \mathrm{mths}$ & $6 \mathrm{mths}$ & 12 month & longrun \\
\hline \multirow[t]{5}{*}{ Austria } & 2 & 0.30 & 0.28 & 0.55 & 0.73 & 0.62 & 0.61 & 0.18 & 0.16 & 0.45 & 0.71 & 0.64 & 0.61 \\
\hline & 3 & 0.36 & 0.38 & 0.56 & 0.67 & 0.66 & 0.61 & 0.36 & 0.39 & 0.56 & 0.67 & 0.66 & 0.61 \\
\hline & 4 & 0.36 & 0.50 & 0.72 & 0.75 & 0.60 & 0.63 & 0.24 & 0.40 & 0.65 & 0.74 & 0.61 & 0.63 \\
\hline & 7 & 0.03 & 0.02 & 0.02 & 0.02 & 0.03 & 0.02 & 0.00 & 0.00 & -0.01 & -0.02 & -0.04 & 0.02 \\
\hline & 8 & 0.21 & 0.29 & 0.44 & 0.47 & 0.43 & 0.44 & 0.16 & 0.26 & 0.42 & 0.47 & 0.43 & 0.44 \\
\hline \multirow[t]{7}{*}{ Belgium } & 2 & 0.25 & 0.25 & 0.78 & 1.10 & 1.36 & 0.72 & 0.18 & 0.17 & 0.70 & 1.18 & 1.39 & 0.72 \\
\hline & 3 & 0.46 & 0.48 & 0.48 & 0.48 & 0.48 & 0.85 & 0.37 & 0.38 & 0.38 & 0.38 & 0.38 & 0.85 \\
\hline & 4.1 & 0.52 & 0.53 & 0.87 & 1.13 & 1.01 & 0.92 & 0.48 & 0.48 & 0.81 & 1.10 & 1.03 & 0.92 \\
\hline & 4.2 & 0.41 & 0.36 & 0.57 & 0.71 & 0.83 & 0.85 & 0.53 & 0.46 & 0.67 & 0.77 & 0.84 & 0.85 \\
\hline & 5 & 0.24 & 0.30 & 0.43 & 0.47 & 0.31 & 0.34 & 0.34 & 0.42 & 0.54 & 0.50 & 0.27 & 0.34 \\
\hline & 8 & 0.26 & 0.26 & 0.22 & 0.08 & -0.42 & 0.83 & 0.52 & 0.59 & 0.64 & 0.65 & 0.57 & 0.83 \\
\hline & 9 & 0.00 & 0.00 & 0.00 & 0.00 & 0.00 & 0.02 & -0.02 & -0.02 & 0.00 & 0.02 & 0.02 & 0.02 \\
\hline \multirow[t]{7}{*}{ Finland } & 2 & 0.47 & 0.60 & 0.64 & 0.64 & 0.64 & 1.07 & 0.32 & 0.40 & 0.43 & 0.43 & 0.43 & 1.07 \\
\hline & 3 & 0.48 & 0.55 & 0.56 & 0.56 & 0.56 & 0.96 & 0.34 & 0.39 & 0.39 & 0.39 & 0.39 & 0.96 \\
\hline & 5 & 0.76 & 0.39 & 1.11 & 1.19 & 0.93 & 0.93 & 0.75 & 0.38 & 1.11 & 1.19 & 0.94 & 0.93 \\
\hline & 6 & 0.61 & 0.97 & 1.29 & 1.01 & 0.89 & 0.90 & 0.78 & 1.07 & 1.35 & 0.99 & 0.91 & 0.90 \\
\hline & 7 & 0.15 & 0.10 & 0.16 & 0.17 & 0.20 & 0.20 & 0.04 & 0.03 & 0.07 & 0.10 & 0.16 & 0.20 \\
\hline & 8 & -0.05 & -0.04 & -0.05 & -0.07 & -0.08 & -0.10 & 0.09 & 0.07 & 0.08 & 0.04 & -0.02 & -0.10 \\
\hline & 10 & 0.11 & 0.11 & 0.20 & 0.36 & 0.36 & 0.36 & 0.05 & 0.05 & 0.16 & 0.36 & 0.36 & 0.36 \\
\hline \multirow[t]{4}{*}{ France } & 4 & 0.55 & 0.30 & 1.22 & 1.13 & 0.68 & 0.79 & 0.37 & 0.20 & 1.21 & 1.09 & 0.65 & 0.79 \\
\hline & 5 & 0.26 & 0.36 & 0.54 & 0.67 & 0.72 & 0.72 & 0.14 & 0.27 & 0.46 & 0.63 & 0.72 & 0.72 \\
\hline & 8 & 0.93 & 0.93 & 1.16 & 1.10 & 0.94 & 0.98 & 0.76 & 0.76 & 0.98 & 1.08 & 0.95 & 0.98 \\
\hline & 9 & 0.10 & 0.11 & 0.11 & 0.11 & 0.11 & -0.05 & -0.14 & -0.15 & -0.15 & -0.15 & -0.15 & -0.05 \\
\hline \multirow{8}{*}{ Germany } & 2 & 0.06 & 0.09 & 0.11 & 0.11 & 0.11 & 0.47 & 0.18 & 0.27 & 0.34 & 0.36 & 0.36 & 0.47 \\
\hline & 3 & 0.12 & 0.15 & 0.17 & 0.17 & 0.17 & 0.38 & 0.16 & 0.20 & 0.21 & 0.22 & 0.22 & 0.38 \\
\hline & 4 & 0.24 & 0.31 & 0.42 & 0.48 & 0.50 & 0.63 & 0.06 & 0.08 & 0.11 & 0.12 & 0.13 & 0.63 \\
\hline & 5 & 0.18 & 0.29 & 0.51 & 0.73 & 0.53 & 0.50 & 0.13 & 0.20 & 0.45 & 0.70 & 0.57 & 0.50 \\
\hline & 8.1 & 0.51 & 0.63 & 0.60 & 0.62 & 0.64 & 0.73 & 0.42 & 0.51 & 0.46 & 0.49 & 0.54 & 0.73 \\
\hline & 8.2 & 0.46 & 0.69 & 0.84 & 0.84 & 0.82 & 0.82 & 0.45 & 0.69 & 0.84 & 0.84 & 0.82 & 0.82 \\
\hline & 9.1 & 0.12 & 0.15 & 0.19 & 0.14 & 0.05 & 0.27 & 0.11 & 0.13 & 0.16 & 0.11 & -0.01 & 0.27 \\
\hline & 9.2 & 0.21 & 0.30 & 0.33 & 0.28 & 0.20 & 0.76 & 0.27 & 0.39 & 0.44 & 0.41 & 0.36 & 0.76 \\
\hline Ireland & 1 & 0.43 & 0.48 & 0.52 & 0.64 & 0.77 & 0.78 & 0.32 & 0.36 & 0.41 & 0.47 & 0.59 & 0.78 \\
\hline & 2 & 0.51 & 0.59 & 0.68 & 0.72 & 0.65 & 0.63 & 0.64 & 0.75 & 0.80 & 0.79 & 0.64 & 0.63 \\
\hline & 4 & 0.43 & 0.46 & 0.48 & 0.52 & 0.66 & 0.70 & 0.34 & 0.37 & 0.38 & 0.41 & 0.44 & 0.70 \\
\hline & 5 & 0.43 & 0.41 & 0.48 & 0.56 & 0.63 & 0.66 & 0.31 & 0.30 & 0.29 & 0.29 & 0.27 & 0.66 \\
\hline & 6 & 1.07 & 0.99 & 1.01 & 1.01 & 1.01 & 1.01 & 1.08 & 0.99 & 1.01 & 1.01 & 1.01 & 1.01 \\
\hline & 9.1 & 0.14 & 0.15 & 0.15 & 0.15 & 0.15 & 0.22 & 0.13 & 0.14 & 0.14 & 0.14 & 0.14 & 0.22 \\
\hline & 9.2 & 0.24 & 0.22 & 0.22 & 0.22 & 0.22 & 0.28 & 0.23 & 0.22 & 0.22 & 0.22 & 0.22 & 0.28 \\
\hline Italy & 2 & 0.14 & 0.41 & 0.60 & 0.55 & 0.60 & 0.60 & 0.20 & 0.44 & 0.61 & 0.56 & 0.60 & 0.60 \\
\hline & 4.1 & 0.28 & 0.32 & 0.49 & 0.64 & 0.63 & 0.62 & 0.05 & 0.05 & 0.25 & 0.59 & 0.66 & 0.62 \\
\hline & 4.2 & 0.29 & 0.42 & 0.53 & 0.74 & 0.84 & 0.81 & 0.01 & 0.01 & 0.07 & 0.54 & 0.87 & 0.81 \\
\hline & 5 & 0.59 & 0.36 & 1.16 & 0.98 & 0.71 & 0.72 & 0.52 & 0.31 & 1.16 & 0.99 & 0.70 & 0.72 \\
\hline & 7 & 0.21 & 0.29 & 0.27 & 0.33 & 0.40 & 0.42 & 0.05 & 0.07 & -0.01 & 0.16 & 0.37 & 0.42 \\
\hline & 8 & 0.34 & 0.45 & 0.43 & 0.33 & -0.03 & 0.64 & 0.21 & 0.27 & 0.19 & -0.02 & -0.79 & 0.64 \\
\hline & 10 & 0.19 & 0.26 & 0.30 & 0.30 & 0.28 & 0.35 & 0.04 & 0.06 & 0.04 & -0.02 & -0.18 & 0.35 \\
\hline Netherlands & 2 & 0.15 & 0.23 & 0.31 & 0.41 & 0.52 & 0.56 & 0.17 & 0.26 & 0.34 & 0.44 & 0.53 & 0.56 \\
\hline & 4 & 0.82 & 0.47 & 0.75 & 0.89 & 0.95 & 0.98 & 0.72 & 0.42 & 0.68 & 0.83 & 0.92 & 0.98 \\
\hline & 7 & 0.00 & 0.00 & 0.00 & 0.00 & -0.02 & 0.04 & 0.01 & 0.01 & 0.01 & 0.00 & -0.01 & 0.04 \\
\hline & 8.1 & -0.02 & -0.02 & -0.03 & -0.04 & -0.04 & 0.52 & 0.25 & 0.32 & 0.45 & 0.52 & 0.55 & 0.52 \\
\hline & 8.2 & 0.10 & 0.13 & 0.14 & 0.14 & 0.14 & 0.56 & 0.28 & 0.37 & 0.41 & 0.41 & 0.41 & 0.56 \\
\hline Portugal & 2 & 0.36 & 0.37 & 0.54 & 0.62 & 0.65 & 0.83 & 0.16 & 0.17 & 0.27 & 0.36 & 0.43 & 0.83 \\
\hline & 3 & -0.09 & 0.22 & 0.34 & 0.42 & 0.45 & 0.46 & -0.34 & 0.20 & 0.31 & 0.40 & 0.45 & 0.46 \\
\hline & 4.1 & 0.14 & 0.20 & 0.36 & 0.44 & 0.39 & 0.38 & 0.13 & 0.19 & 0.35 & 0.44 & 0.39 & 0.38 \\
\hline & 4.2 & 0.47 & 0.32 & 0.72 & 0.74 & 0.62 & 0.63 & 0.35 & 0.23 & 0.68 & 0.76 & 0.61 & 0.63 \\
\hline & 8.1 & 0.39 & 0.47 & 0.49 & 0.49 & 0.49 & 1.01 & 0.41 & 0.50 & 0.52 & 0.52 & 0.52 & 1.01 \\
\hline & 8.2 & 0.13 & 0.23 & 0.37 & 0.51 & 0.53 & 0.51 & 0.09 & 0.20 & 0.35 & 0.50 & 0.53 & 0.51 \\
\hline Spain & 2 & 0.19 & 0.32 & 0.44 & 0.45 & 0.34 & 0.84 & 0.03 & 0.06 & 0.04 & -0.06 & -0.36 & 0.84 \\
\hline & 3 & 0.45 & 0.20 & 0.83 & 0.73 & 0.64 & 0.63 & 0.56 & 0.25 & 0.87 & 0.73 & 0.64 & 0.63 \\
\hline & 4 & 0.63 & 0.87 & 1.05 & 0.86 & 0.86 & 0.85 & 0.78 & 0.91 & 1.07 & 0.86 & 0.86 & 0.85 \\
\hline & 5 & 0.53 & 0.20 & 0.89 & 0.84 & 0.71 & 0.72 & 0.19 & 0.07 & 0.80 & 0.86 & 0.70 & 0.72 \\
\hline & 6 & 0.43 & 0.60 & 0.91 & 1.02 & 0.80 & 0.81 & 0.36 & 0.54 & 0.86 & 1.01 & 0.81 & 0.81 \\
\hline & 7 & 0.21 & 0.23 & 0.32 & 0.36 & 0.37 & 0.63 & 0.15 & 0.16 & 0.22 & 0.25 & 0.26 & 0.63 \\
\hline & 8 & 0.54 & 0.52 & 0.58 & 0.65 & 0.72 & 0.76 & 0.30 & 0.30 & 0.41 & 0.56 & 0.69 & 0.76 \\
\hline & 10.1 & 0.65 & 0.63 & 0.88 & 1.09 & 1.00 & 1.00 & 0.65 & 0.62 & 0.88 & 1.09 & 1.00 & 1.00 \\
\hline & 10.2 & 0.23 & 0.32 & 0.37 & 0.38 & 0.38 & 0.79 & 0.24 & 0.34 & 0.40 & 0.41 & 0.41 & 0.79 \\
\hline
\end{tabular}

